\title{
National scale variability in forest stand variables among regions of provenances in Spain
}

\author{
Daniel Moreno-Fernández ${ }^{1} \cdot$ Isabel Cañellas ${ }^{1} \cdot$ Álvaro Rubio-Cuadrado $^{2} \cdot$ Iciar Alberdi $^{1}$
}

Received: 9 July 2019 / Accepted: 12 March 2020 / Published online: 4 May 2020

(C) INRAE and Springer-Verlag France SAS, part of Springer Nature 2020

\begin{abstract}
- Key message An in-depth characterization of the forests of 10 dominant species by stand variables at national scale showed, that overall, stands growing in the southernmost regions of Spain display low regeneration. Otherwise, the relationships between stand variables and geographic location are species dependent. Similarly, the degree of inter and interregional variability varies strongly among species.

- Context The regions of provenance can potentially be used as units with uniform ecological, phenotypic, and genetic traits to characterize forests.

- Aims Our objective was to characterize forests through stand variables at national scale for the 10 most widespread dominant tree species in Spain (five Pinaceae and five Fagaceae species) using the regions of provenance as ecologically homogeneous areas.

- Methods We used the National Forest Inventory as the dataset and multivariate analyses of variance with a bootstrapping and principal coordinates analysis for the statistical evaluation.

- Results Overall, the mean diameter of adult trees was negatively related to recruitment variables, and the mean height of adult trees was negatively related to shrub coverage and number of shrub species. The statistical analyses revealed significant differences between regions of provenance for all variables. The regions of provenance where Pinus sylvestris, P. nigra, P. pinea, Quercus suber, and $Q$. ilex are dominant, displayed a large variability among regions. In contrast, the regions of provenance for $P$. halepensis, $Q$. pyrenaica, and $Q$. faginea displayed a small low inter-regional variability.

- Conclusion Forest management as well as climate conditions shaped deeply forests, which lead to differences on stand variables among provenances by species. Stands growing on the southernmost locations, overall, are more prone to the forecasted climate change due to the low rates of regeneration.
\end{abstract}

Keywords Forest resources $\cdot$ Sustainable management $\cdot$ Reproductive material $\cdot$ Monitoring $\cdot$ MANOVA

Handling Editor: Tuula Packalen \& Klemens Schadauer

Contributions of the co-authors

DM-F: running the statistical analyses, writing the manuscript. IC: idea conception, writing the manuscript. AR-C: support with the statistical analyses, writing the manuscript IA: idea conception, writing the manuscript, support with the NFI dataset. All authors read and approved the final manuscript

This article is part of the topical collection on Forest information for bioeconomy outlooks at European level

Daniel Moreno-Fernández

danielmorenofdez@gmail.com

Isabel Cañellas

canellas@inia.es

Álvaro Rubio-Cuadrado

alvarorubiocuadrado@gmail.com
Iciar Alberdi

alberdi.iciar@inia.es

INIA-CIFOR, Ctra La Coruña km 7.5, 28040 Madrid, Spain

2 MONTES (School of Forest Engineering and Natural Resources), Universidad Politécnica de Madrid, 28040 Madrid, Spain 


\section{Introduction}

The characterization of forest resources at larger spatial scales is increasingly necessary not only with regard to biodiversity conservation but also to maintain the goods and services provided by forests (Rosenqvist et al. 2003). Forest biodiversity can be assessed in terms of genetics, structural complexity, landscape, ecosystem services, and species diversity (Lindenmayer et al. 2000). Indeed, genetic features, composition, and structure at population/ecosystem level are critical for developing effective forest management strategies as well as sound conservation strategies (Bussotti et al. 2015). Hence, several studies have attempted to describe forest characteristics, such as site quality (Moreno-Fernández et al. 2018a), wood density (Jordan et al. 2008), biodiversity (Alberdi et al. 2014), tree growth (Vannoppen et al. 2019), or forest reproductive material (Skrøppa and Fjellstad 2017), at local, country, or even global scale.

Iberian forests grow on sites with different climates and soils (Ruiz-Benito et al. 2012). In fact, the Iberian Peninsula encompasses three biogeographical regions. Furthermore, Iberian forests provide services and products beyond wood, such as mushrooms, pine nuts, resin, or cork (Calama et al. 2010). The silvicultural guidelines, indeed, vary sharply depending on the main objective of the stand. All of this is reflected in the state of the forests, which is primarily quantitatively assessed through stand variables and stand structure. Several studies have attempted to characterize forest structure and stand variables at fine scales (Vergarechea et al. 2019). However, information on forest features at large spatial scales is scarce (Vayreda et al. 2013; Moreno-Fernández et al. 2019). The characterization of forest ecosystems at national scale requires a large dataset with a sampling intensity sufficient to cover the whole territory. National Forest Inventories (NFIs) usually fulfill these requirements (Vayreda et al. 2013). Indeed, NFIs have proved to be a useful tool to characterize forest typologies (Reque and Bravo 2008; MorenoFernández et al. 2018a).

Characterizing forests by stand attributes at coarse scale, however, is not an easy task since many factors and processes, such as long-term forest management, stand development stage, as well as local adaptation and phenotypic plasticity play a role in the current forest stands (Yen 2015). Areas with uniform ecological conditions and phenotypic and genetic features, such as regions of provenance (provenance, hereafter), can contribute to the characterization of forest stands at coarse spatial scales. The European Directive EC 105/99 defines the provenance as "the area or group of areas subject to sufficiently uniform ecological conditions in which stands or seed sources showing similar phenotypic or genetic characters are found, taking into account altitudinal boundaries where appropriate."

Many studies have focused on the genetic variation and genetic structure among the provenances (Mingeot et al.
2016). Several studies have also evaluated the extent to which tree traits vary among provenances (Nabais et al. 2018). Additionally, provenances have been used as intra-specific geographical units in progeny trials (also termed common garden, provenance trials, and genetic trials) in order to investigate the response of population features, such as morphological characters (Gandour et al. 2007), tree allometry (VizcaínoPalomar et al. 2017), survival, and growth (Esteban et al. 2010), to environmental conditions. Most of the studies agreed that these population features and tree trait differ among provenances. Other authors (Benito-Garzón et al. 2019) have used the provenances to consider local adaptation and phenotypic plasticity in species distribution models under current and future climatic conditions. Phenotypic plasticity can help populations to persist under climate change. In this respect, much effort has been directed towards selecting the provenances best adapted to future climatic conditions (Gross et al. 2017). However, to our knowledge, the characterization of the provenances according to stand variables is hitherto lacking, although these variables are related to forest biodiversity (McGeoch et al. 2007).

The main aim of this work was to characterize the forests of the 10 most widespread Spanish tree species through stand variables using the provenances as spatial units with uniform ecological, phenotypic, and genetic features. We also aimed to test whether significant differences in stand variables exist among the provenances. For the purposes of our study, we used upperstory and lowerstory variables extracted from the Spanish NFI. We expect to find significant differences among provenances with respect to the stand variables studied, larger regeneration rates together with larger values of basal area, and number of trees in colder and more humid sites with respect to sites subjected to harsher climatic conditions although the response to climate conditions might vary on species, i.e., inter-specific variability. Finally, we expect to find that species in geographical proximity would be more similar to each other although we assume that forest management could alter this geographical pattern.

\section{Material and methods}

\subsection{Spanish regions of provenance and species studied}

Spain uses two methods to delineate the regions of provenance, a divisive and an agglomerative method. The divisive method divides the territory into ecologically homogenous units assuming that the ecological variables used to characterize the regions are important for plant growth. This method allows the same regions to be defined for all species but does not consider special features of the species such as patterns of distribution or genetic variation. The agglomerative method 
groups the stands of a given species with similar phenotypic, genetic, or ecological features to form a region of provenance. The selection of ecological, phenotypic, and genetic features to delineate differs among countries. In Spain, the following variables have been used: geographical information, altitude, climate, soil, information on neutral genetic markers, on field trials, and on provenance trials as well as growth rates and adaptation traits (Alía et al. 2009). Thus, each species is present in several provenances which are expected to define the variation pattern of the species more precisely. The agglomerative method has been developed for the main tree species whereas the divisive method is used to delineate the provenances of secondary tree species in Spain (Alía et al. 2005; Auñón et al. 2011). In this case, we use the provenances defined by the agglomerative method for 10 widespread, native species of the two most important families (Pinaceae and Fagaceae) employed in the forestry sector from both economic and ecological perspectives: Pinus sylvestris L., P. nigra Arn., P. pinaster Ait., P. pinea L., P. halepensis Mill, Quercus pyrenaica Willd., Q. faginea Lam., Q. suber L., Q. ilex L., and Fagus sylvatica L.. These species account for more than $90 \%$ of the volume of the native species in Spain according to the NFI.

\subsection{Spanish National Forest Inventory and stand variable selection}

For the purposes of our study, we used data from the Third NFI, conducted between 1997 and 2007. The NFI consists of permanent sampling points established in woodland areas on a $1 \times 1 \mathrm{~km}$ grid. At each sampling point, adult trees are identified and measured in four concentric circular plots with radii of $5,10,15$, and $25 \mathrm{~m}$ according to their diameter at breast height (dbh) (Alberdi et al. 2016). We expanded the attributes of the trees measured in each concentric plot to per-hectare values by considering the plot area (Table 1).

The NFI classifies the regeneration within the 5-m-radius plot into four categories according to their $\mathrm{dbh}$ and height (Table 2). The NFI groups the number of plants in the regeneration categories into four categorical abundance classes. In the largest regeneration category (4), the number of plants is counted. We merged the three smallest regeneration categories

Table 1 Radius of the plots established at each sampling point of the National Forest Inventory, diameter at breast height (dbh) threshold, as well as the expansion factor to values per hectare of each plot

\begin{tabular}{lll}
\hline Plot radius $(\mathrm{m})$ & dbh threshold & Expansion factor \\
\hline 5 & $\mathrm{dbh} \geq 7.5 \mathrm{~cm}$ & 127.32 \\
10 & $\mathrm{dbh} \geq 12.5 \mathrm{~cm}$ & 31.83 \\
15 & $\mathrm{dbh} \geq 22.5 \mathrm{~cm}$ & 14.15 \\
25 & $\mathrm{dbh} \geq 42.5 \mathrm{~cm}$ & 5.09 \\
\hline
\end{tabular}

into the seedling cohort (plants with $\mathrm{dbh}<2.5 \mathrm{~cm}$ ) whereas the largest regeneration categories were merged as the sapling cohort (height $\geq 1.3 \mathrm{~m}$ and $\mathrm{dbh}<7.5 \mathrm{~cm}$ ). As with the adult trees, the number of seedlings and saplings was expanded to per-hectare values (further details of the regeneration field protocol are shown in Table 2).

The NFI estimates the coverage (\%) of each shrub species in the 10-m-radius plot. Finally, we calculated the shrub species number at each sampling point.

In order to characterize the provenances, we use both upperstory and lowerstory variables. In the upperstory, we consider (i) number of adult trees per hectare $(N)$, (ii) mean diameter of the adult trees $(D n, \mathrm{~cm})$, (iii) mean height of adult trees $(H)$, (iv) basal area $\left(G, \mathrm{~m}^{2} \mathrm{ha}^{-1}\right)$; and for the lowerstory: (v) number of seedlings per hectare (Nse), (vi) number of saplings per hectare (Nsa), (vii) shrub coverage ( $\mathrm{ShCov}, \%)$, and (viii) number of shrub species (Rshrub).

The Spanish NFI records information on the presence of silvicultural operations, such as regeneration felling, thinning or pruning, and the occurrence of forest fires. This information is useful to account for the effect of perturbations on the stand features.

In this study, we selected those plots in which the basal area dominance of the reference species was equal to or above $80 \%$. Regions sampled with a minimum of 20 plots were used. The mean attributes of the stands can be found in Table 3, and attributes per region of provenance and the maps of the provenances studied are shown in Annex 1, Tables 5, 6, 7, 8, 9, 10, 11, 12, 13, 14 and Annex 2, respectively.

\subsection{Data analysis}

In order to test whether there are significant differences in the multivariate means for the different provenances, we used a two-way multivariate analysis of variance approach (MANOVA) which incorporates a parametric bootstrap routine with 1000 bootstrap runs (Konietschke et al. 2015; Friedrich et al. 2018). The parametric bootstrap methods overcome the assumptions of multivariate normality and covariance homogeneity among groups for the classical MANOVA. The parametric bootstrap routine also allows MANOVA to handle unbalanced designs (Krishnamoorthy and Lu 2010; Konietschke et al. 2015; Friedrich and Pauly 2018). In the two-way MANOVA, we included a provenance factor and the perturbation factor (binary variable, $0=$ no perturbation, $1=$ perturbation) as well as the interaction provenance $\times$ per turbation to account for the effect of silvicultural operations and that of wildfires. We calculated the modified ANOVAtype statistic (MATS) as well as the $p$ value given by the parametric resampling routine to determine the significance of the factors (Friedrich and Pauly 2018). When the global hypothesis was rejected at $5 \%$ level, we performed the univariate analysis using the parametric bootstrap MATS and the 
Table 2 Regeneration categories established, recording methods, cohort classification in the 5-m plot of the National Forest Inventory (NFI) sampling points, and expansion factor to values per hectare

\begin{tabular}{llll}
\hline NFI regeneration categories & Recording method & Cohort & Expansion factor \\
\hline (1) Height $<30 \mathrm{~cm}$ & Abundance classes $(0,1,2,3)$ & Seedlings & 127.32 \\
(2) $30 \leq$ height $<130 \mathrm{~cm}$ & Abundance classes $(0,1,2,3)$ & Seedlings & 127.32 \\
(3) Height $\geq 130 \mathrm{~cm}$ and dbh $<2.5 \mathrm{~cm}$ & Abundance classes $(0,1,2,3)$ & Saplings & 127.32 \\
(4) Height $\geq 1.3 \mathrm{~m}$ and $2.5 \leq \mathrm{dbh}<7.5 \mathrm{~cm}$ & Count (number of plants) & Saplings & 127.32 \\
\hline
\end{tabular}

Abundance classes: 0 ( 0 plants in the plot), 1 ( 2 to 4 plants in the plot), 2 ( 5 to 15 plants), and 3 (more than 15 plants). $d b h$ diameter at breast height
Bonferroni adjustment to investigate the univariate outcomes that caused the rejection. Furthermore, principal coordinate analysis (PCoA) was used to visualize the patterns of the provenances in a two-dimensional reduced space, i.e., biplots, by adding the $95 \%$ confidence intervals of the weighted averages of the provenances.

All the statistical analyses were performed with R 3.6.0. software (R Core Team 2019). MANOVA and related analyses were conducted with the "MANOVA.wide" function of the "MANOVA.RM" package (Friedrich et al. 2018), and the PCoAs analyses were carried out using the "cmdscale" and "ordiellipse" functions of the "vegan" package (Oksanen et al. 2018). Finally, we mapped the provenances of each species and colored them using the red and green colors from the RGB palette of ArcGIS 10.3 (ESRI 2015). Red color $[0,255]$ was assigned to the $X$ coordinates (first
PCoA axis) of the centroids of the provenances and the green color $[0,255]$ to the $Y$ coordinates (second PCoA axis) of the centroid whereas the blue color was set to zero. We assigned red $=0$ to the leftmost centroid and red $=255$ to the rightmost centroid. The same applies to the green color but with the lowermost and uppermost centroids. Thus, we attempted to represent the variability detected in the PCoAs into the geographical space.

\section{Results}

\subsection{Inter-species assessment of stand attributes}

The biplots based on the upperstory and lowerstory stand variables revealed similar relationships of variables among

hectare (Nse), number of saplings per hectare (Nsa), shrub coverage (ShCov in \%), and number of shrub species (Rshrub) for the regions of provenance of the 10 studied species
Table 3 Number of plots ( $n$ ), number of regions of provenance (Prov) considered in this study and mean values of number of adult trees per hectare $(N)$, mean diameter of the adult trees $(D n$ in $\mathrm{cm})$, mean height of adult trees $(H$ in $\mathrm{m})$, basal area $\left(G\right.$ in $\left.\mathrm{m}^{2} \mathrm{ha}^{-1}\right)$, number of seedlings per

\begin{tabular}{|c|c|c|c|c|c|c|c|c|c|c|}
\hline Species & $n$ & Prov & $N$ & $D n$ & $H$ & $G$ & Nse & $N s a$ & ShCov & Rshrub \\
\hline Pinus sylvestris & 3858 & 15 & $\begin{array}{l}661 \\
(515)\end{array}$ & $\begin{array}{l}21.1 \\
(7.2)\end{array}$ & $\begin{array}{l}10.2 \\
(3.4)\end{array}$ & $\begin{array}{l}21.8 \\
(13.6)\end{array}$ & $\begin{array}{c}7609 \\
(5411)\end{array}$ & $\begin{array}{l}777 \\
(1144)\end{array}$ & $\begin{array}{l}32.5 \\
(28.7)\end{array}$ & $\begin{array}{l}4 \\
(2)\end{array}$ \\
\hline Pinus nigra & 2825 & 8 & $\begin{array}{l}560 \\
(545)\end{array}$ & $\begin{array}{l}20.3 \\
(8.6)\end{array}$ & $\begin{array}{l}8.7 \\
(3.0)\end{array}$ & $\begin{array}{l}14.4 \\
(10.8)\end{array}$ & $\begin{array}{c}6715 \\
(4546)\end{array}$ & $\begin{array}{l}636 \\
(866)\end{array}$ & $\begin{array}{l}44.3 \\
(28.9)\end{array}$ & $\begin{array}{l}5 \\
\text { (3) }\end{array}$ \\
\hline Pinus pinaster & 4104 & 21 & $\begin{array}{l}464 \\
(451)\end{array}$ & $\begin{array}{l}23.7 \\
(9.0)\end{array}$ & $\begin{array}{l}11.0 \\
(4.2)\end{array}$ & $\begin{array}{l}17.7 \\
(13.2)\end{array}$ & $\begin{array}{c}2941 \\
(2837)\end{array}$ & $\begin{array}{l}419 \\
(876)\end{array}$ & $\begin{array}{l}64.8 \\
(45.1)\end{array}$ & $\begin{array}{l}5 \\
(3)\end{array}$ \\
\hline Pinus pinea & 1454 & 6 & $\begin{array}{l}268 \\
(279)\end{array}$ & $\begin{array}{l}26.8 \\
(11.2)\end{array}$ & $\begin{array}{l}8.8 \\
(3.1)\end{array}$ & $\begin{array}{l}11.6 \\
(8.1)\end{array}$ & $\begin{array}{c}2310 \\
(2467)\end{array}$ & $\begin{array}{l}183 \\
(483)\end{array}$ & $\begin{array}{l}41.8 \\
(36.3)\end{array}$ & $\begin{array}{l}5 \\
\text { (3) }\end{array}$ \\
\hline Pinus halepensis & 8649 & 20 & $\begin{array}{l}357 \\
(337)\end{array}$ & $\begin{array}{l}19.4 \\
(7.3)\end{array}$ & $\begin{array}{l}7.9 \\
(2.7)\end{array}$ & $\begin{array}{l}9.0 \\
(7.2)\end{array}$ & $\begin{array}{c}4205 \\
(3723)\end{array}$ & $\begin{array}{l}408 \\
(654)\end{array}$ & $\begin{array}{l}68.2 \\
(35.6)\end{array}$ & $\begin{array}{l}8 \\
(4)\end{array}$ \\
\hline Quercus pyrenaica & 2747 & 16 & $\begin{array}{l}607 \\
(646)\end{array}$ & $\begin{array}{l}19.3 \\
(13.1)\end{array}$ & $\begin{array}{l}8.7 \\
(2.8)\end{array}$ & $\begin{array}{l}11.2 \\
(9.9)\end{array}$ & $\begin{array}{c}4260 \\
(2774)\end{array}$ & $\begin{array}{l}895 \\
(1371)\end{array}$ & $\begin{array}{l}48.4 \\
(37.2)\end{array}$ & $\begin{array}{l}4 \\
(2)\end{array}$ \\
\hline Quercus faginea & 1268 & 12 & $\begin{array}{l}543 \\
(597)\end{array}$ & $\begin{array}{l}17.8 \\
(14.0)\end{array}$ & $\begin{array}{l}6.7 \\
(2.4)\end{array}$ & $\begin{array}{l}8.5 \\
(8.4)\end{array}$ & $\begin{array}{c}7642 \\
(4542)\end{array}$ & $\begin{array}{l}1142 \\
(1381)\end{array}$ & $\begin{array}{l}49.6 \\
(32.7)\end{array}$ & $\begin{array}{l}5 \\
(3)\end{array}$ \\
\hline Quercus suber & 1447 & 9 & $\begin{array}{l}253 \\
(322)\end{array}$ & $\begin{array}{l}30.1 \\
(15.2)\end{array}$ & $\begin{array}{l}7.6 \\
(2.3)\end{array}$ & $\begin{array}{l}11.6 \\
(8.4)\end{array}$ & $\begin{array}{c}3969 \\
(3634)\end{array}$ & $\begin{array}{l}268 \\
(649)\end{array}$ & $\begin{array}{l}68.7 \\
(44.4)\end{array}$ & $\begin{array}{l}7 \\
(4)\end{array}$ \\
\hline Quercus ilex & 10,582 & 23 & $\begin{array}{l}343 \\
(539)\end{array}$ & $\begin{array}{l}25.8 \\
(17.3)\end{array}$ & $\begin{array}{l}6.1 \\
(1.8)\end{array}$ & $\begin{array}{l}6.5 \\
(6.1)\end{array}$ & $\begin{array}{c}4037 \\
(3959)\end{array}$ & $\begin{array}{l}774 \\
(1418)\end{array}$ & $\begin{array}{l}36.1 \\
(36.3)\end{array}$ & $\begin{array}{l}4 \\
(3)\end{array}$ \\
\hline Fagus sylvatica & 2115 & 12 & $\begin{array}{l}570 \\
(512)\end{array}$ & $\begin{array}{l}28.2 \\
(14.7)\end{array}$ & $\begin{array}{l}15.5 \\
(5.2)\end{array}$ & $\begin{array}{l}25.5 \\
(11.4)\end{array}$ & $\begin{array}{c}3438 \\
3290)\end{array}$ & $\begin{array}{l}657 \\
(1224)\end{array}$ & $\begin{array}{l}17.0 \\
(24.2)\end{array}$ & $\begin{array}{l}2 \\
(2)\end{array}$ \\
\hline
\end{tabular}

Standard deviation is shown in brackets. Plots with $80 \%$ dominance in basal area of the reference species were selected 
species (Figs. 1 and 2). In general, the mean diameter of adult trees was negatively related to recruitment variables (number of seedlings and number of saplings) while the mean height of adult trees was negatively related to shrub features (shrub coverage and shrub species number). However, the mean diameter of $F$. sylvatica was not related to shrub features although the basal area of this species negatively influenced shrub features. In the case of $P$. halepensis, the biplot from the PCoA revealed a negative relationship between the mean diameter and density variables (basal area and number of adult trees per hectare).
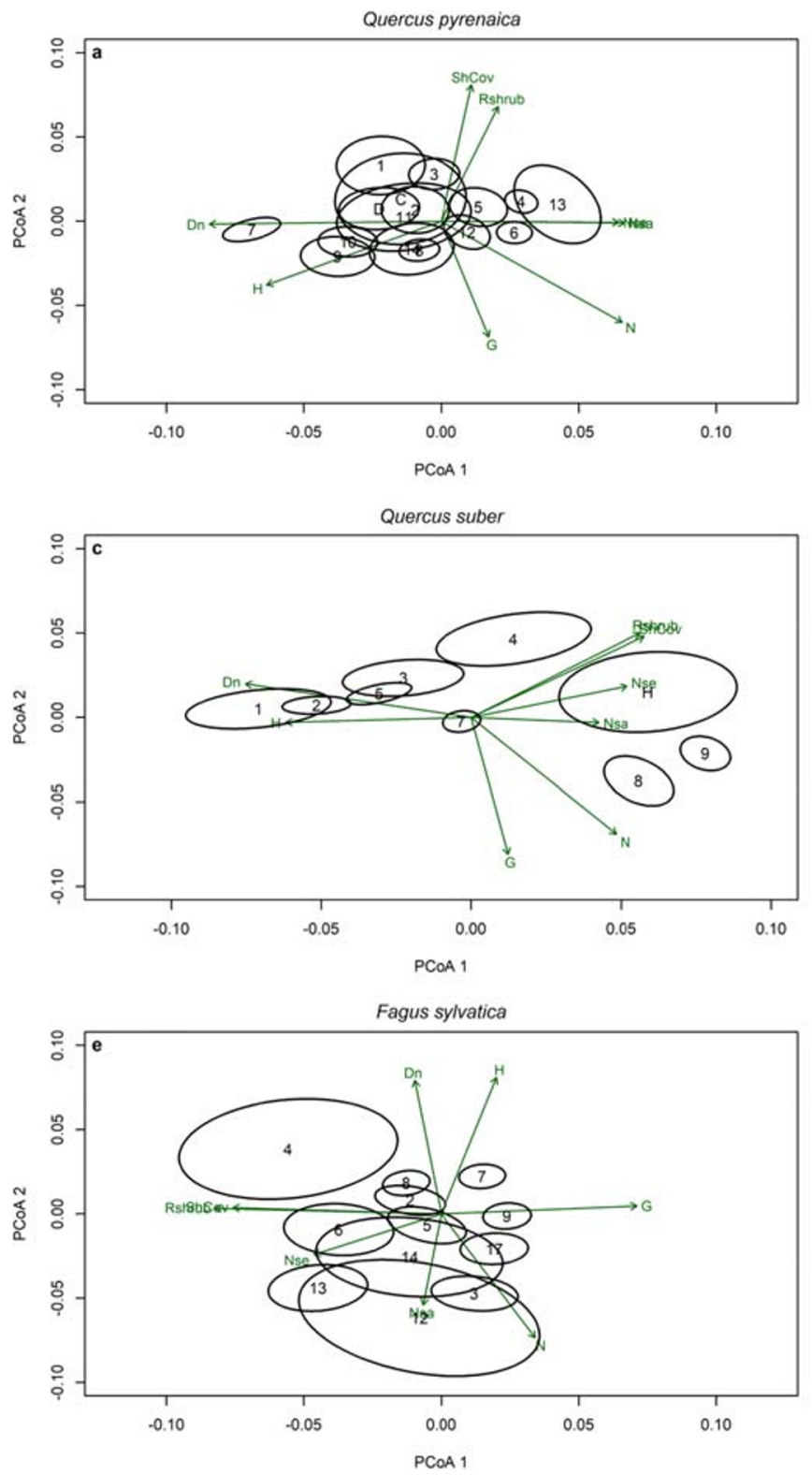

Fig. 1 Biplots based on the upperstory and lowerstory data for the Pinaceae species. Green arrows represent the upperstory and lowerstory variables: number of adult trees per hectare $(N)$, mean diameter of the adult trees $(D n)$, mean height of adult trees $(H)$, basal area $(G)$, number of seedlings per hectare (Nse), number of saplings per hectare ( $N s a)$, shrub

\subsection{Variations in stand variables among regions of provenance of the species studied}

We found that the resampling-based $p$ values of the provenance for the two-way MANOVA approach were lower than 0.001 (Table 4) for all the species, implying that there are significant differences among provenances with respect to the eight stand variables studied. The resampling-based $p$ values for the univariate analysis using the parametric bootstrap MATS were always smaller than 0.05 (data not shown) indicating that all the variables contribute to the
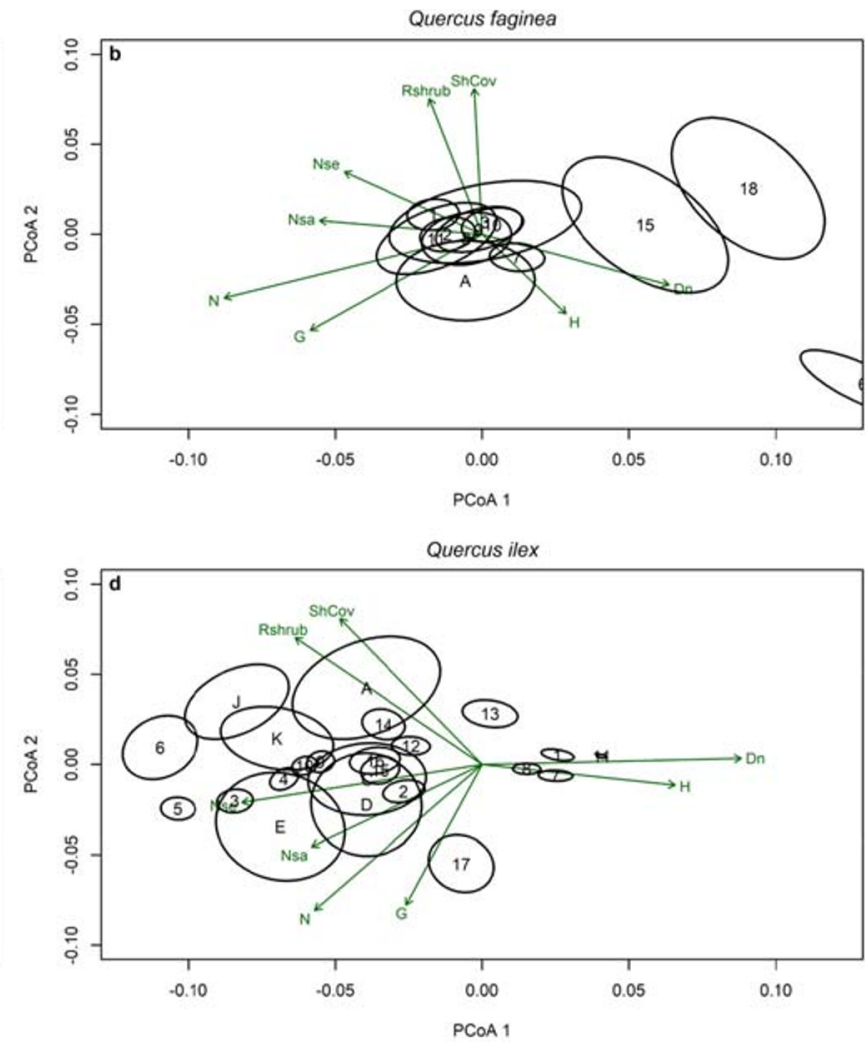

coverage (ShCov) and number of shrub species (Rshrub). Ellipses represent $95 \%$ confidence intervals around the centroids of the regions of provenance. The numbers in the centroids refer to the regions of provenance code (see Annexes 1 and 2) 

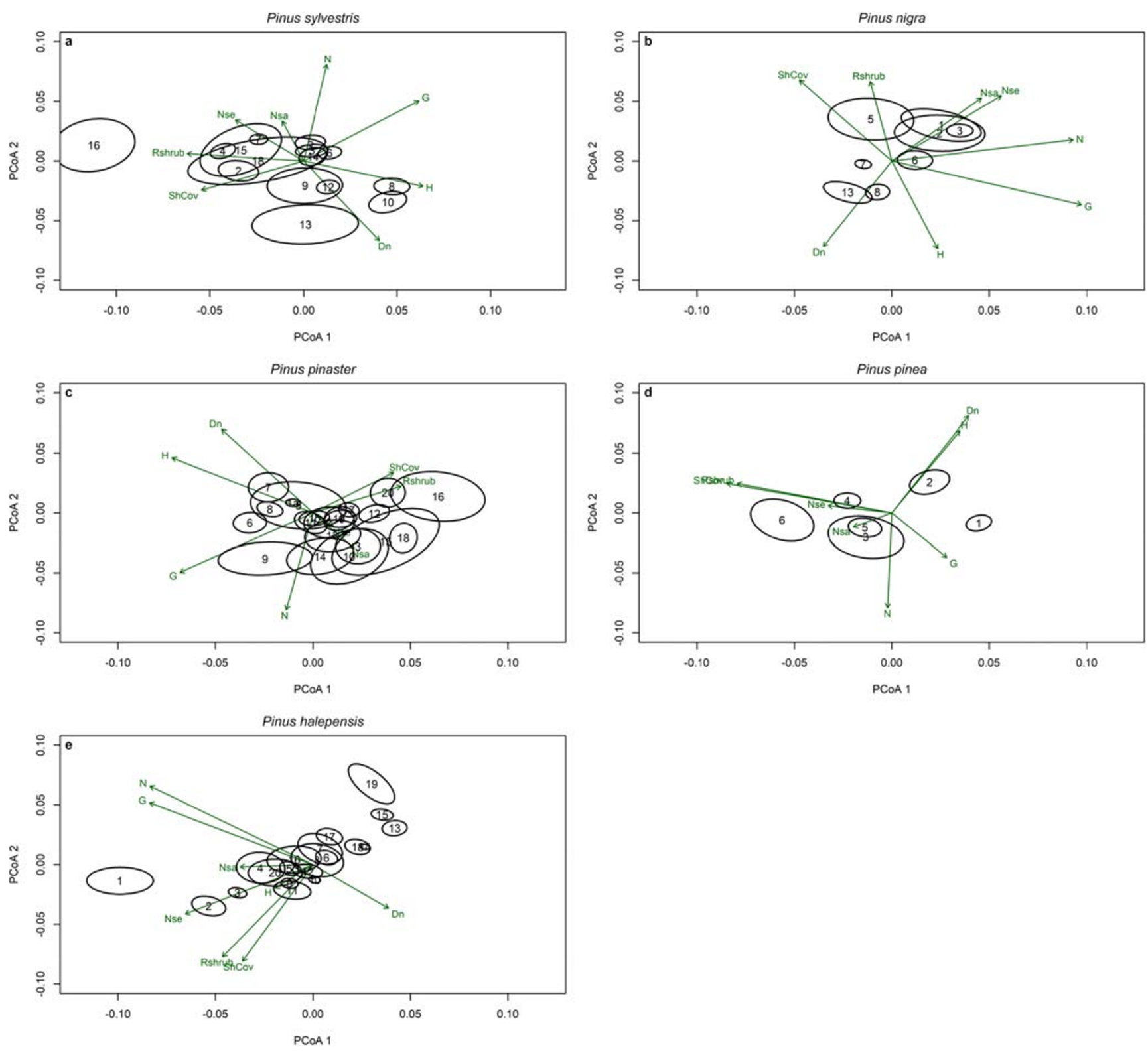

Fig. 2 Biplots based on the upperstory and lowerstory data for the Fagaceae species. Green arrows represent the upperstory and lowerstory variables: number of adult trees per hectare $(N)$, mean diameter of the adult trees $(D n)$, mean height of adult trees $(H)$, basal area $(G)$, number of seedlings per hectare (Nse), number of saplings per

hectare ( $N s a$ ), shrub coverage (ShCov) and number of shrub species (Rshrub). Ellipses represent 95\% confidence intervals around the centroids of the regions of provenance. The numbers in the centroids refer to the regions of provenance code (see Annexes 1 and 2)

significant difference among provenances for the 10 species studied. Overall, we found a significant effect of the perturbation factor and the interaction provenance $\times$ perturbation indicating that the silvicultural treatments and the wildfires contributed to explain the variation of forests attributes (Table 4).

The PCoAs procedure placed several provenances close to the center of the biplots (coordinates 0,0 ) overlapping the 95\% confidence intervals (Figs. 1 and 2). This indicates weak associations with the PCoAs axes and nonsignificant differences among these provenances. This is especially evident for

some RPs of P. sylvestris, P. pinaster, P. halepensis, $Q$. faginea, $Q$. pyrenaica, and $F$. sylvatica.

The PCoAs located the geographically closer provenances together whereas the provenances which are more distant from each other geographically tend to be more separated in the biplots for some species, such as P. nigra, $Q$. ilex, and $Q$. suber. In the case of $P$. nigra, the biplot (Fig. 1b) placed the RPs 8 and 13, which correspond to southern locations, in close proximity in the reduced space, while the RPs 1, 2, 3, 5, and 6 (Pyrenees, Pre-Pyrenean, and eastern locations; Annex 2) are grouped closely in the reduced space of the 
Table 4 Modified ANOVA-type statistic (MATS) and the resampling-based $p$ values for the two-way multivariate analysis of variance approach

\begin{tabular}{|c|c|c|c|c|c|c|}
\hline \multirow[t]{2}{*}{ Species } & \multicolumn{2}{|l|}{ Provenance } & \multicolumn{2}{|c|}{ Perturbation } & \multicolumn{2}{|c|}{ Provenance $\times$ perturbation } \\
\hline & MATS & $p$ value & MATS & $p$ value & MATS & $p$ value \\
\hline Pinus sylvestris & 5438.05 & $<0.001$ & 150.52 & $<0.001$ & 405.50 & $<0.001$ \\
\hline Pinus nigra & 1910.25 & $<0.001$ & 25.98 & 0.344 & 163.22 & 0.001 \\
\hline Pinus pinaster & 4864.54 & $<0.001$ & 118.64 & $<0.001$ & 440.98 & $<0.001$ \\
\hline Pinus pinea & 1798.97 & $<0.001$ & 24.74 & 0.006 & 41.63 & 0.465 \\
\hline Pinus halepensis & 9361.97 & $<0.001$ & 145.41 & $<0.001$ & 376.40 & $<0.001$ \\
\hline Quercus pyrenaica & 2699.67 & $<0.001$ & 61.91 & $<0.001$ & 259.98 & 0.068 \\
\hline Quercus faginea & 1657.42 & $<0.001$ & 14.81 & 0.142 & 181.54 & 0.039 \\
\hline Quercus suber & 2910.46 & $<0.001$ & 45.58 & $<0.001$ & 177.26 & $<0.001$ \\
\hline Quercus ilex & $14,101.39$ & $<0.001$ & 64.41 & 0.001 & 505.79 & 0.027 \\
\hline Fagus sylvatica & 1376.27 & $<0.001$ & 79.06 & $<0.001$ & 227.39 & 0.018 \\
\hline
\end{tabular}

biplot. Furthermore, southern provenances of $P$. nigra are characterized by a large mean diameter, low regeneration, and low intra-regional variability (small 95\% confidence intervals of the weighted averages) whereas the Pyrenees, PrePyrenean, and eastern locations present more seedlings and saplings, a greater number of tree and shrub species, and more intra-regional variability (large 95\% confidence intervals of the weighted averages). This phenomenon of large variations in the variance among provenances for a given species is known as the heterogeneity of variances or heteroscedastic variances. This is especially evident in the case of $Q$. ilex (Fig. 2d) where provenances 1, 7, 8, and 11 (western Spain) have small $95 \%$ confidence intervals of the weighted averages, i.e., low variance, whereas provenances $\mathrm{A}, \mathrm{D}$, or $\mathrm{E}$ have large $95 \%$ confidence intervals of the weighted averages, i.e., high variance. There is also a relationship between geographical distribution and biplot distribution for $P$. pinea. In this respect, the biplot placed the provenances 1 and 2 (central locations) and the provenances 3,4 , and 5 (southern locations) in close proximity, with provenance 6 (northeast Spain) being separated from the rest. Central provenances are characterized by large mean plot diameter and height and by low regeneration and low intra-regional variability, while provenance 6 displays the opposite characteristics and the central locations present intermediate characteristics.

In the case of $Q$. ilex and $Q$. suber, the PCoAs biplots grouped the provenances (Fig. 2c, d, respectively) located in open woodlands (provenances 1 and 11 for $Q$. ilex and provenances $1,2,3,4$, and 5 for $Q$. suber) close together. The biplots of $Q$. ilex and $Q$. suber indicate that provenances in open woodlands are characterized by large diameters, low regeneration, and open shrub coverage.

The correspondence between the geographical locations of the provenances and the positions in the two-dimensional reduced space is not so evident for other species, such as $P$. sylvestris and $P$. pinaster. Some patterns, however, can be identified. The RPs of P. sylvestris located in Central Spain (provenances 8, 9, 10, 12, and 13; Annex 2, Figures 3 and 4) are situated in relative proximity in the reduced space (Fig. 1a) and generally show larger diameter, lower number of younger individuals, and less shrub coverage than some of the provenances located in the North of Spain (provenances 4 and 7). Similarly, the provenances of $P$. pinaster located in the centralwestern area (provenances $5,6,7$, and 8 , with high diameter and height and low regeneration, shrub coverage, and number of shrub species) or in the central-eastern area of Spain (provenances $9,10,11,12,14,15,16$, and 18 , in general displaying the opposite relationships with the stand variables) are situated, respectively, close together in the reduced space of the biplot.

\section{Discussion}

To our knowledge, this is the first attempt to classify and describe forest stands at such as broad scale. Classical multivariate techniques, such as traditional MANOVA, analysis of similitudes, or permutation analysis of variance, do not satisfy one or several statistical assumptions (non-normality, unbalanced design and heteroscedasticity among groups), and therefore, the results provided through these techniques may be biased and unreliable (Krishnamoorthy and Lu 2010). The approach employed in this study, the two-way MANOVA with parametric bootstrap, is capable of dealing with non-normally distributed data with variance heterogeneity as well as unbalanced designs (Krishnamoorthy and Lu 2010; Friedrich et al. 2018).

The results of the MANOVAs and the PCoAs reveal a significant influence of the provenances on stand features (upperstory and lowerstory variables) for the 10 species studied. The influence of long-term forest management on the stand attributes cannot be neglected and contributes to the interpretation of the results. In fact, the perturbation factor emerged as a significant factor to explain forest variability. 
Clear examples of the effects of forest management on stand variables at coarse spatial scale are the stands of $Q$. ilex and Q. suber. Agrosilvopastoral open woodlands of both species are common in the west and south-west of the Iberian Peninsula (provenances 1 and 11 of $Q$. ilex and provenances $1,2,3,4$, and 5 of Q. suber) (Simões et al. 2016; MorenoFernández et al. 2019). These systems are originated from thinning of closed stands to combine tree, agriculture, and livestock exploitation (Gea-Izquierdo et al. 2011; Acácio et al. 2017). On the other hand, more closed stands are predominant in other locations of the Iberian Peninsula (Serrada et al. 2017). As regards the agrosilvopastoral open woodlands, the stand characteristics reported in this study (large diameter and low regeneration) are in agreement with previous findings at finer scales (Moreno-Fernández et al. 2019). Several authors suggested that the intensive management, which includes high pressure of livestock and shrub removal, precludes the establishment of new individuals and leads to the senescence of standing trees (Simões et al. 2016; Moreno-Fernández et al. 2019). Furthermore, stands with large diameters are in the development stage before the installation of new cohorts. The negative relationship between mean diameter of $P$. halepensis and density variables can be due to the harsh sites where this species grows in Spain. The stands of $P$. halepensis usually are located on sites characterized by an intense summer drought (De Luis et al. 2011). Additionally, thinnings are usually neglected and all together result in dense stands of trees with small diameters. In contrast to other species, the basal area of F. sylvatica was the main variable related to the shrubs variables. This is due to the low light transmittance in closed stands of $F$. sylvatica, which impedes the development of understory plants (Barbier et al. 2008).

Lack of regeneration of $P$. nigra in southern (provenances 8 and 13) and Central (provenance 7) locations has previously been reported, for instance, by Tíscar et al. (2011) and LucasBorja et al. (2012), respectively. We also detected this SouthNorth regeneration pattern for $P$. sylvestris and this is supported by previous findings at a finer scale. Indeed, several studies point to the difficulty of achieving natural regeneration of P. sylvestris in Central (Pardos et al. 2007) and southern Spain (Castro et al. 2004), particularly because of pronounced drought during summer. The abovementioned South-North pattern of tree species regeneration in the Iberian Peninsula is attributed to harsher climatic conditions in the southernmost locations (Matías et al. 2018; Moreno-Fernández et al. 2019). Vilà-Cabrera et al. (2011) identified that the lack of regeneration is positively related to adult tree mortality in the case of P. sylvestris, so that it is expectable that the largest mortality rates of this species take place in the southern locations. The South-North pattern is also expected to have some influence on tree features such as the tree height-diameter allometry (Vizcaíno-Palomar et al. 2016, 2017).
Our findings revealed strong differences among the provenances of $P$. pinea. This species grows, generally, on sandy soils but under different climatic conditions. For instance, provenance 2 is located on mountainous area (above $800 \mathrm{~m}$ asl) with a continental-Mediterranean climate (Mayoral et al. 2015) whereas provenance 4 is located close to the sea level and the temperatures are soft with influence of the Atlantic Ocean. This is expectable that this broad range of site conditions affects the stand variables of $P$. pinea among provenances. This is recognized that this species shows low genetic diversity (SánchezGómez et al. 2011), and the phenotypic plasticity of adult trees is of greater importance than adaptive differentiation among provenances in terms of survival or tree growth (Mutke et al. 2010). In this regard, Pardos and Calama (2018) reported that this adaptive plasticity allows $P$. pinea to adapt to a broad range of environmental conditions. The provenance with the highest rates of regeneration (provenance 6) is located in North-East of Spain (Coll et al. 2013) showed that the conditions in this area are favorable for tree regeneration whereas provenances 1 and 2 usually lack of regeneration, as Calama and Montero (2007) and Manso et al. (2013) stated. In fact, the lack of regeneration in provenances 1 and 2 is linked to the larger diameters found in these provenances with respect to the other provenances.

We expected, however, to find important differences among the provenances of $P$. pinaster due to its diverse genetic traits (González-Martínez et al. 2002), phenotypical variability (Vizcaíno-Palomar et al. 2017), and the alternative management strategies (Diéguez-Aranda et al. 2005; Rodríguez-García et al. 2015). This species, which presents regional adaptations (González-Martínez et al. 2002), is subdivided into two subspecies (atlantica in the Atlantic basin, provenances $1 \mathrm{a}$ and $1 \mathrm{~b}$, and mesogeensis in the rest of the Iberian Peninsula), with different management strategies and growth rates. Subspecies atlantica is subjected to intensive management for wood and paper production whereas the subspecies mesogeensis presents substantial differences in terms of ecology and management, ranging from vigorous stands used for wood production and resin production to low density stands with lack of regeneration (Diéguez-Aranda et al. 2005; Rodríguez-García et al. 2015). Atlantic provenances (provenances $1 \mathrm{a}$ and $1 \mathrm{~b}$ ) are situated in close proximity in the biplot, although they are not separated from the rest of the provenances. The scarce regeneration found in the regions of central-western Spain supports the findings of previous studies (Vergarechea et al. 2019).

One of the factors that might contribute to explain the observed differences among provenances is the stand age. Spatial trends in stand age should be due to the reforestation programs. Although three periods of reforestation can be distinguished in Spain (Valbuena-Carabaña et al. 2010), there 
have been national plans affecting all forest land, so no spatial trends in stand age trend have been identified along the analyzed species distribution area. The significant influence of the provenances on stand attributes is also expected to be linked to local adaptation and phenotypic plasticity to site conditions (Gárate-Escamilla et al. 2019; Benito-Garzón et al. 2019), which have been shown to vary widely across the study area (Moreno-Fernández et al. 2018a). However, disentangling the contribution of phenotypic plasticity and local adaptation to intra-specific variations is beyond the scope of this work, and common garden trials would be necessary to obtain proper inferences (Brancalion et al. 2018).

Despite the significant influence of the provenance with respect to the upperstory and lowerstory variables, the closeness of many provenances centroids to the biplot center suggests moderate variability among provenances for some species (e.g., P. halepensis, Q. pyrenaica, and Q. faginea). The large variability of forest studied within a given provenance can hinder the detection of more significant differences among provenances. In fact, the minimum mean diameter of the plots used to conduct this study was $7.5 \mathrm{~cm}$. This means that several stand development stages were considered (Harvey and Brais 2007). It is also important to note the influence of origin, both the vegetative origin and the origin of the seed used for reforestations, on the stand variables. As regards the vegetative origin, Fagaceae species form both coppices and standards. Hence, some of these species have been managed as coppices to produce firewood over prolonged periods (Cañellas et al. 2004; Serrada et al. 2017). Furthermore, foreign forest reproductive material or reproductive material from other provenances have sometimes been used in reforestations, especially in the reforestations carried out in the first half of the last century (Ennos et al. 1998). This could lead to a mixture native and nonnative stands of a given species within the same provenance. For instance, reproductive material from the subspecies $P$. pinaster messogensis was used in reforestations in northern Spain where the subspecies atlantica grows naturally (Alía et al. 1996). In the case of P. nigra, seeds of a native subspecies and other foreign subspecies were planted (Moreno-Fernández et al. 2018b). Therefore, the mixing of stands of different origins (vegetative origin, i.e., seeds or shoots, and geographical seed origin) across the provenances may introduce "noise" in the analyses. In this regard, RuizBenito et al. (2012) found that autochthonous pine populations show larger regeneration than non-autochthonous pine populations. Finally, it is important to note that some provenances were not included in the analyses because they fell short of the minimum number of plots (20) with basal area dominance of the reference species equal to or greater than $80 \%$. This could also hinder the detection of other differences among provenances.

\section{Conclusion}

The fact that our results the country scale are in accordance with previous findings at finer scales, confirms the suitability of our approach from an ecological perspective. Our findings show that upperstory and lowerstory features vary among provenances for most of the species studied although provenances in geographical proximity to each other usually present similar stand attributes. Hence, in terms of stand characterization, the use of forest reproductive material from regions which are close to one another would appear to be appropriate for forestry operations, although the projected changes in climate conditions could require the use of material from population subjected to hasher conditions.

The results obtained in this study provide a tool for largescale planning as well as in forest policy decision-making at national scale, by identifying relevant differences in the stand structure characteristics between the different regions by species. For instance, in sites where the poor regeneration is located, especially southernmost locations, it is expectable that the stands growing on these sites are more prone to the forecasted climate change.

This methodology could be extended to other countries. In fact, it should be possible to assess the way in stand variables of some widespread species, such as P. sylvestris or F. sylvatica, varies across Europe. In this work, however, we have not accounted for the local adaptation or phenotypic plasticity. Then, further steps must be oriented towards disentangling the role of genetic variability, phenotypic plasticity, climate change, and forest management on forest features and structural indices at large spatial scales for a better understanding of the forests as well as for the conservation of forest resources.

Acknowledgments The authors also thank Adam Collins for revising the English grammar and Sarah Friedrich for her support with MANOVA.RM R package. We acknowledge the contributions of the reviewers and the editors during the reviewing process.

Funding information This work has been funded through the Agreement between the Ministry of Agriculture and INIA EG17-042. A. R-C received a FPU predoctoral contract from the Ministry of Education, Culture, and Sport (FPU15/03533).

Data availability The datasets generated during and/or analyzed during the current study are available in the Spanish National Forest Inventory repository, https://www.miteco.gob.es/es/biodiversidad/servicios/bancodatos-naturaleza/informacion-disponible/ifn 3 base datos 1 25.aspx and https://www.miteco.gob.es/es/biodiversidad/servicios/banco-datosnaturaleza/informacion-disponible/ifn3_base_datos_26_50.aspx

\section{Compliance with ethical standards}

Conflict of interest The authors declare that they have no conflict of interest. 
Annex 1 Average stand attributes

for the studied species by regions

of provenance

Table 5 Mean stand attributes for the regions of provenance of Pinus sylvestris. Standard deviation between brackets

\begin{tabular}{|c|c|c|c|c|c|c|c|c|c|c|}
\hline Prov & $n$ & $N$ & $D n$ & $H t$ & $G$ & Nse & $N s a$ & ShCov & Rtree & Rshrub \\
\hline 2 & 212 & $\begin{array}{l}574 \\
(400)\end{array}$ & $\begin{array}{l}22.4 \\
(7.3)\end{array}$ & $\begin{array}{l}10.2 \\
(3.6)\end{array}$ & $\begin{array}{l}20.9 \\
(11.1)\end{array}$ & $\begin{array}{l}9826 \\
(6131)\end{array}$ & $\begin{array}{l}663 \\
(859)\end{array}$ & $\begin{array}{l}50.4 \\
(26.6)\end{array}$ & $\begin{array}{l}2 \\
(1)\end{array}$ & $\begin{array}{l}6 \\
(3)\end{array}$ \\
\hline 3 & 408 & $\begin{array}{l}700 \\
(453)\end{array}$ & $\begin{array}{l}20.3 \\
(5.8)\end{array}$ & $\begin{array}{l}10.6 \\
(3.8)\end{array}$ & $\begin{array}{l}24.6 \\
(15.7)\end{array}$ & $\begin{array}{l}8343 \\
(4952)\end{array}$ & $\begin{array}{l}1062 \\
(1326)\end{array}$ & $\begin{array}{l}32.2 \\
(25.3)\end{array}$ & $\begin{array}{l}2 \\
(1)\end{array}$ & $\begin{array}{l}4 \\
(2)\end{array}$ \\
\hline 4 & 376 & $\begin{array}{l}671 \\
(559)\end{array}$ & $\begin{array}{l}18.2 \\
(5.6)\end{array}$ & $\begin{array}{l}8.2 \\
(2.5)\end{array}$ & $\begin{array}{l}16.7 \\
(10.8)\end{array}$ & $\begin{array}{l}10,226 \\
(4291)\end{array}$ & $\begin{array}{l}1049 \\
(1193)\end{array}$ & $\begin{array}{l}41.9 \\
(28.1)\end{array}$ & $\begin{array}{l}2 \\
(1)\end{array}$ & $\begin{array}{l}5 \\
(3)\end{array}$ \\
\hline 5 & 354 & $\begin{array}{l}708 \\
(500)\end{array}$ & $\begin{array}{l}21.2 \\
(6.4)\end{array}$ & $\begin{array}{l}10 \\
(3.1)\end{array}$ & $\begin{array}{l}25.3 \\
(15.7)\end{array}$ & $\begin{array}{l}10,818 \\
(5173)\end{array}$ & $\begin{array}{l}947 \\
(1334)\end{array}$ & $\begin{array}{l}23.8 \\
(20.6)\end{array}$ & $\begin{array}{l}2 \\
(1)\end{array}$ & $\begin{array}{l}4 \\
(2)\end{array}$ \\
\hline 6 & 426 & $\begin{array}{l}699 \\
(493)\end{array}$ & $\begin{array}{l}21 \\
(5.9)\end{array}$ & $\begin{array}{l}9.8 \\
(2.8)\end{array}$ & $\begin{array}{l}23.7 \\
(12.1)\end{array}$ & $\begin{array}{l}7045 \\
(4275)\end{array}$ & $\begin{array}{l}770 \\
(1041)\end{array}$ & $\begin{array}{l}25.1 \\
(24.5)\end{array}$ & $\begin{array}{l}2 \\
(1)\end{array}$ & $\begin{array}{l}3 \\
(2)\end{array}$ \\
\hline 7 & 707 & $\begin{array}{l}760 \\
(498)\end{array}$ & $\begin{array}{l}18.5 \\
(4.7)\end{array}$ & $\begin{array}{l}10.6 \\
(2.6)\end{array}$ & $\begin{array}{l}20.2 \\
(10.7)\end{array}$ & $\begin{array}{l}10,930 \\
(5558)\end{array}$ & $\begin{array}{l}1015 \\
(1068)\end{array}$ & $\begin{array}{l}36.8 \\
(29.2)\end{array}$ & $\begin{array}{l}2 \\
(1)\end{array}$ & $\begin{array}{l}5 \\
(3)\end{array}$ \\
\hline 8 & 396 & $\begin{array}{l}670 \\
(607)\end{array}$ & $\begin{array}{l}25 \\
(9.8)\end{array}$ & $\begin{array}{l}12.4 \\
(4.8)\end{array}$ & $\begin{array}{l}28.1 \\
(16.9)\end{array}$ & $\begin{array}{l}2777 \\
(2443)\end{array}$ & $\begin{array}{l}531 \\
(1461)\end{array}$ & $\begin{array}{l}34.6 \\
(33)\end{array}$ & $\begin{array}{l}2 \\
(1)\end{array}$ & $\begin{array}{l}3 \\
(2)\end{array}$ \\
\hline 9 & 80 & $\begin{array}{l}629 \\
(584)\end{array}$ & $\begin{array}{l}21.1 \\
(8.8)\end{array}$ & $\begin{array}{l}8.9 \\
(4.2)\end{array}$ & $\begin{array}{l}18.2 \\
(13.5)\end{array}$ & $\begin{array}{l}3037 \\
(2688)\end{array}$ & $\begin{array}{l}422 \\
(906)\end{array}$ & $\begin{array}{l}41.7 \\
(42.1)\end{array}$ & $\begin{array}{l}2 \\
(1)\end{array}$ & $\begin{array}{l}3 \\
(2)\end{array}$ \\
\hline 10 & 121 & $\begin{array}{l}515 \\
(508)\end{array}$ & $\begin{array}{l}26.6 \\
(8.6)\end{array}$ & $\begin{array}{l}11 \\
(3.7)\end{array}$ & $\begin{array}{l}24.4 \\
(14.3)\end{array}$ & $\begin{array}{l}1505 \\
(1775)\end{array}$ & $\begin{array}{l}121 \\
(309)\end{array}$ & $\begin{array}{l}28.3 \\
(30.9)\end{array}$ & $\begin{array}{l}2 \\
(1)\end{array}$ & $\begin{array}{l}2 \\
(2)\end{array}$ \\
\hline 12 & 430 & $\begin{array}{l}495 \\
(458)\end{array}$ & $\begin{array}{l}23.3 \\
(7.8)\end{array}$ & $\begin{array}{l}10.4 \\
(3)\end{array}$ & $\begin{array}{l}18.8 \\
(12.8)\end{array}$ & $\begin{array}{l}5239 \\
(3396)\end{array}$ & $\begin{array}{l}483 \\
(917)\end{array}$ & $\begin{array}{l}26.7 \\
(25.8)\end{array}$ & $\begin{array}{l}2 \\
(1)\end{array}$ & $\begin{array}{l}3 \\
(2)\end{array}$ \\
\hline 13 & 24 & $\begin{array}{l}196 \\
(157)\end{array}$ & $\begin{array}{l}25.3 \\
(7.9)\end{array}$ & $\begin{array}{l}8.2 \\
(2.7)\end{array}$ & $\begin{array}{l}10.7 \\
(10)\end{array}$ & $\begin{array}{l}3337 \\
(2667)\end{array}$ & $\begin{array}{l}233 \\
(418)\end{array}$ & $\begin{array}{l}20.9 \\
(22.7)\end{array}$ & $\begin{array}{l}2 \\
(1)\end{array}$ & $\begin{array}{l}3 \\
(2)\end{array}$ \\
\hline 14 & 255 & $\begin{array}{l}684 \\
(572)\end{array}$ & $\begin{array}{l}19.5 \\
(5.8)\end{array}$ & $\begin{array}{l}8.7 \\
(2.4)\end{array}$ & $\begin{array}{l}18.6 \\
(11.7)\end{array}$ & $\begin{array}{l}6290 \\
(3435)\end{array}$ & $\begin{array}{l}677 \\
(971)\end{array}$ & $\begin{array}{l}18.4 \\
(20.5)\end{array}$ & $\begin{array}{l}2 \\
(1)\end{array}$ & $\begin{array}{l}3 \\
(2)\end{array}$ \\
\hline 15 & 27 & $\begin{array}{l}624 \\
(427)\end{array}$ & $\begin{array}{l}20.2 \\
(6)\end{array}$ & $\begin{array}{l}8.6 \\
(1.8)\end{array}$ & $\begin{array}{l}18.2 \\
(9.2)\end{array}$ & $\begin{array}{l}10,497 \\
(4586)\end{array}$ & $\begin{array}{l}1193 \\
(925)\end{array}$ & $\begin{array}{l}28.6 \\
(22.7)\end{array}$ & $\begin{array}{l}2 \\
(1)\end{array}$ & $\begin{array}{l}5 \\
(2)\end{array}$ \\
\hline 16 & 21 & $\begin{array}{l}591 \\
(336)\end{array}$ & $\begin{array}{l}16.8 \\
(3.6)\end{array}$ & $\begin{array}{l}7.9 \\
(2)\end{array}$ & $\begin{array}{l}14.3 \\
(8.5)\end{array}$ & $\begin{array}{l}12,211 \\
(3760)\end{array}$ & $\begin{array}{l}1085 \\
(627)\end{array}$ & $\begin{array}{l}68.2 \\
(27)\end{array}$ & $\begin{array}{l}2 \\
(1)\end{array}$ & $\begin{array}{l}9 \\
(3)\end{array}$ \\
\hline 18 & 21 & $\begin{array}{l}901 \\
(499)\end{array}$ & $\begin{array}{l}15.9 \\
(4.9)\end{array}$ & $\begin{array}{l}8.1 \\
(3.8)\end{array}$ & $\begin{array}{l}20.5 \\
(14.4)\end{array}$ & $\begin{array}{l}819 \\
(1502)\end{array}$ & $\begin{array}{l}327 \\
(580)\end{array}$ & $\begin{array}{l}73.7 \\
(28.3)\end{array}$ & $\begin{array}{l}2 \\
(1)\end{array}$ & $\begin{array}{l}3 \\
(2)\end{array}$ \\
\hline
\end{tabular}

Prov, region of provenance; $n$, number of plots with basal area of $P$. sylvestris larger than $80 \% ; N$, number of adult trees per hectare; Dn, mean diameter of the adult trees in $\mathrm{cm} ; H$, mean height of adult trees in $\mathrm{m} ; G$, basal area in $\mathrm{m}^{2} \mathrm{ha}^{-1}$; Nse, number of seedlings per hectare; $N s a$, number of saplings per hectare; ShCov, shrub coverage in \%; Rtree, number of tree species; and Rshrub, number of shrub species 
Table 6 Mean stand attributes for the regions of provenance of Pinus nigra. Standard deviation between brackets

\begin{tabular}{|c|c|c|c|c|c|c|c|c|c|c|}
\hline Prov & $n$ & $N$ & $D n$ & $H t$ & $G$ & Nse & Nsa & ShCov & Rtree & Rshrub \\
\hline 1 & 63 & $\begin{array}{l}777 \\
(607)\end{array}$ & $\begin{array}{l}16.2 \\
(5.2)\end{array}$ & $\begin{array}{l}8.1 \\
(2.3)\end{array}$ & $\begin{array}{l}15.9 \\
(11.7)\end{array}$ & $\begin{array}{l}10,047 \\
(4447)\end{array}$ & $\begin{array}{l}655 \\
(646)\end{array}$ & $\begin{array}{l}44.3 \\
(25.2)\end{array}$ & $\begin{array}{l}2 \\
(1)\end{array}$ & $\begin{array}{l}7 \\
(3)\end{array}$ \\
\hline 2 & 46 & $\begin{array}{l}801 \\
(647)\end{array}$ & $\begin{array}{l}16.2 \\
(6.6)\end{array}$ & $\begin{array}{l}7.7 \\
(2.1)\end{array}$ & $\begin{array}{l}14.6 \\
(10.2)\end{array}$ & $\begin{array}{l}9492 \\
(4601)\end{array}$ & $\begin{array}{l}726 \\
(645)\end{array}$ & $\begin{array}{l}42.6 \\
(21.9)\end{array}$ & $\begin{array}{l}2 \\
(1)\end{array}$ & $\begin{array}{l}5 \\
(2)\end{array}$ \\
\hline 3 & 545 & $\begin{array}{l}834 \\
(589)\end{array}$ & $\begin{array}{l}16.7 \\
(5)\end{array}$ & $\begin{array}{l}9 \\
(2.6)\end{array}$ & $\begin{array}{l}16.7 \\
(10.2)\end{array}$ & $\begin{array}{l}9651 \\
(4373)\end{array}$ & $\begin{array}{l}977 \\
(1020)\end{array}$ & $\begin{array}{l}45.8 \\
(28.3)\end{array}$ & $\begin{array}{l}2 \\
(1)\end{array}$ & $\begin{array}{l}6 \\
(3)\end{array}$ \\
\hline 5 & 52 & $\begin{array}{l}556 \\
(415)\end{array}$ & $\begin{array}{l}19 \\
(6.4)\end{array}$ & $\begin{array}{l}8.8 \\
(2.9)\end{array}$ & $\begin{array}{l}14.1 \\
(10.7)\end{array}$ & $\begin{array}{l}7292 \\
(4311)\end{array}$ & $\begin{array}{l}693 \\
(786)\end{array}$ & $\begin{array}{l}66.3 \\
(36.3)\end{array}$ & $\begin{array}{l}2 \\
(1)\end{array}$ & $\begin{array}{l}8 \\
(3)\end{array}$ \\
\hline 6 & 257 & $\begin{array}{l}530 \\
(491)\end{array}$ & $\begin{array}{l}20.8 \\
(7.4)\end{array}$ & $\begin{array}{l}8.4 \\
(2.4)\end{array}$ & $\begin{array}{l}15.2 \\
(10.6)\end{array}$ & $\begin{array}{l}7907 \\
(4575)\end{array}$ & $\begin{array}{l}789 \\
(955)\end{array}$ & $\begin{array}{l}33.3 \\
(22.5)\end{array}$ & $\begin{array}{l}2 \\
(1)\end{array}$ & $\begin{array}{l}5 \\
(3)\end{array}$ \\
\hline 7 & 1253 & $\begin{array}{l}458 \\
(502)\end{array}$ & $\begin{array}{l}20.8 \\
(7.8)\end{array}$ & $\begin{array}{l}8.8 \\
(3.1)\end{array}$ & $\begin{array}{l}12.8 \\
(10.6)\end{array}$ & $\begin{array}{l}5975 \\
(4144)\end{array}$ & $\begin{array}{l}579 \\
(844)\end{array}$ & $\begin{array}{l}51.2 \\
(30.4)\end{array}$ & $\begin{array}{l}2 \\
(1)\end{array}$ & $\begin{array}{l}5 \\
(2)\end{array}$ \\
\hline 8 & 521 & $\begin{array}{l}483 \\
(513)\end{array}$ & $\begin{array}{l}24.1 \\
(12)\end{array}$ & $\begin{array}{l}8.8 \\
(3.5)\end{array}$ & $\begin{array}{l}15.7 \\
(11.6)\end{array}$ & $\begin{array}{l}4988 \\
(3618)\end{array}$ & $\begin{array}{l}401 \\
(650)\end{array}$ & $\begin{array}{l}32.8 \\
(21.8)\end{array}$ & $\begin{array}{l}2 \\
(1)\end{array}$ & $\begin{array}{l}5 \\
(2)\end{array}$ \\
\hline 13 & 88 & $\begin{array}{l}599 \\
(518)\end{array}$ & $\begin{array}{l}16.7 \\
(6.7)\end{array}$ & $\begin{array}{l}6.4 \\
(1.7)\end{array}$ & $\begin{array}{l}11.3 \\
(9.1)\end{array}$ & $\begin{array}{l}1621 \\
(2393)\end{array}$ & $\begin{array}{l}173 \\
(346)\end{array}$ & $\begin{array}{l}23.8 \\
(21.3)\end{array}$ & $\begin{array}{l}2 \\
(1)\end{array}$ & $\begin{array}{l}4 \\
(2)\end{array}$ \\
\hline
\end{tabular}

Prov, region of provenance; $n$, number of plots with basal area of $P$. nigra larger than $80 \% ; N$, number of adult trees per hectare; Dn, mean diameter of the adult trees in $\mathrm{cm} ; H$, mean height of adult trees in $\mathrm{m} ; G$, basal area in $\mathrm{m}^{2} \mathrm{ha}^{-1} ;$ Nse, number of seedlings per hectare; Nsa, number of saplings per hectare; ShCov, shrub coverage in \%. Rtree, number of tree species; and Rshrub, number of shrub species

Table 7 Stand attributes for the regions of provenance of Pinus pinaster. Standard deviation between brackets

\begin{tabular}{|c|c|c|c|c|c|c|c|c|c|c|}
\hline Prov & $n$ & $N$ & $D n$ & $H t$ & $G$ & Nse & $N s a$ & ShCov & Rtree & Rshrub \\
\hline & & 669 & 21.2 & 7.3 & 21.8 & 3475 & 423 & 38.1 & 2 & 6 \\
\hline \multirow[t]{2}{*}{10} & 28 & (571) & (7.3) & (1.9) & (13.1) & $(2300)$ & $(586)$ & $(23.8)$ & (1) & (2) \\
\hline & & 413 & 25.9 & 9.6 & 18.4 & 4115 & 449 & 51.5 & 2 & 4 \\
\hline \multirow[t]{2}{*}{11} & 131 & (338) & (9.3) & (3) & (10.5) & (3013) & (708) & (26.3) & (1) & (2) \\
\hline & & 437 & 22.3 & 9.2 & 15.3 & 4070 & 365 & 75.9 & 2 & 7 \\
\hline \multirow[t]{2}{*}{12} & 217 & (369) & (6.5) & (2.4) & (11.3) & (3168) & $(702)$ & (39) & (1) & (3) \\
\hline & & 511 & 22.3 & 8.6 & 20.6 & 3846 & 382 & 49.3 & 2 & 6 \\
\hline \multirow[t]{2}{*}{13} & 59 & (413) & (7.3) & (2.9) & (12.9) & (2297) & (718) & (31.9) & (1) & (3) \\
\hline & & 614 & 20.3 & 9.1 & 20.3 & 5224 & 624 & 38.7 & 2 & 4 \\
\hline \multirow[t]{2}{*}{14} & 40 & (327) & (5) & $(2.5)$ & (10.7) & (3038) & (709) & (28.7) & (1) & (3) \\
\hline & & 638 & 19.8 & 7.8 & 18.6 & 4092 & 455 & 61.6 & 2 & 7 \\
\hline \multirow[t]{2}{*}{15} & 30 & (601) & $(7.2)$ & (2.3) & (18) & (2407) & (695) & (35) & (1) & (4) \\
\hline & & 281 & 22.1 & 7.9 & 9.7 & 3791 & 618 & 72.4 & 2 & 9 \\
\hline \multirow[t]{2}{*}{16} & 26 & (322) & $(8.2)$ & (2.9) & $(9.5)$ & $(2280)$ & (1831) & (24.9) & (1) & (3) \\
\hline & & 345 & 25.8 & 9.1 & 15.4 & 4770 & 432 & 51 & 2 & 6 \\
\hline \multirow[t]{2}{*}{17} & 239 & (314) & (8.7) & (2.7) & (9.8) & (3224) & (795) & $(27.5)$ & (1) & (3) \\
\hline & & 447 & 19.6 & 6.2 & 11.1 & 4952 & 390 & 39.5 & 2 & 6 \\
\hline \multirow[t]{2}{*}{18} & 54 & (330) & (6.7) & (1.5) & (6.4) & (3116) & (415) & $(23.8)$ & (1) & (2) \\
\hline & & 380 & 25.6 & 7.9 & 14.7 & 2216 & 209 & 37.8 & 2 & 5 \\
\hline \multirow[t]{2}{*}{19} & 142 & (376) & (9.6) & (2.6) & (11.7) & (2614) & $(514)$ & (27) & (1) & (3) \\
\hline & & 458 & 22.6 & 13.3 & 18 & 2737 & 448 & 81.8 & 2 & 4 \\
\hline $1 \mathrm{a}$ & 1323 & $(376)$ & (8.1) & (4.6) & (12.3) & (2316) & $(844)$ & $(50.2)$ & (1) & (2) \\
\hline
\end{tabular}


Table 7 (continued)

\begin{tabular}{|c|c|c|c|c|c|c|c|c|c|c|}
\hline Prov & $n$ & $N$ & $D n$ & $H t$ & $G$ & Nse & Nsa & ShCov & Rtree & Rshrub \\
\hline & & 596 & 21 & 11.2 & 19.8 & 1846 & 465 & 85.3 & 2 & 4 \\
\hline \multirow[t]{2}{*}{$1 b$} & 417 & $(582)$ & $(8.7)$ & (4.4) & $(17.2)$ & (2042) & $(831)$ & (49.4) & (1) & (2) \\
\hline & & 518 & 23.6 & 8.9 & 19.6 & 1713 & 381 & 88.4 & 2 & 4 \\
\hline \multirow[t]{2}{*}{2} & 65 & (488) & $(7.5)$ & $(2.5)$ & $(11.2)$ & (1504) & $(762)$ & (39.6) & (1) & (2) \\
\hline & & 318 & 26 & 8.4 & 11.1 & 2354 & 295 & 59.6 & 2 & 8 \\
\hline \multirow[t]{2}{*}{20} & 108 & (445) & $(9.5)$ & (2.4) & (9.6) & (2006) & (883) & $(29.1)$ & (1) & (3) \\
\hline & & 538 & 22.9 & 8.5 & 20.4 & 9650 & 934 & 54.6 & 2 & 5 \\
\hline \multirow[t]{2}{*}{3} & 85 & (408) & (7.7) & (2.1) & (12.9) & (4434) & (1096) & $(24.5)$ & (1) & (3) \\
\hline & & 541 & 21 & 10.1 & 14.6 & 2396 & 660 & 69.7 & 2 & 5 \\
\hline \multirow[t]{2}{*}{4} & 302 & (610) & (8.4) & (3.7) & (13.3) & (1817) & (1520) & $(36.6)$ & (1) & (2) \\
\hline & & 430 & 25 & 11.7 & 15 & 3007 & 370 & 49 & 2 & 4 \\
\hline \multirow[t]{2}{*}{5} & 41 & (496) & 10.2) & $(4.5)$ & (10) & (2398) & (691) & $(47.6)$ & (1) & (3) \\
\hline & & 547 & 26.2 & 11.9 & 23.3 & 1893 & 248 & 37.3 & 2 & 4 \\
\hline \multirow[t]{2}{*}{6} & 270 & (599) & (10) & (4) & $(16.3)$ & (1968) & $(688)$ & $(33.2)$ & (1) & (2) \\
\hline & & 319 & 33.2 & 11.4 & 18.7 & 1005 & 63 & 52.7 & 2 & 4 \\
\hline \multirow[t]{2}{*}{7} & 115 & (396) & (13) & (3.5) & $(15.1)$ & (1507) & (217) & $(39.5)$ & (1) & (2) \\
\hline & & 329 & 28.6 & 10.6 & 16.4 & 2016 & 227 & 23.9 & 2 & 3 \\
\hline \multirow[t]{2}{*}{8} & 272 & $(360)$ & (9) & (2.9) & (9.9) & (2812) & (708) & $(23.5)$ & (1) & (2) \\
\hline & & 821 & 21.2 & 10.6 & 32.2 & 2886 & 492 & 52.4 & 2 & 4 \\
\hline 9 & 272 & (444) & (6.6) & (3.7) & (19.4) & (2122) & (952) & $(34.2)$ & (1) & (3) \\
\hline
\end{tabular}

Prov, region of provenance; $n$, number of plots with basal area of $P$. pinaster larger than $80 \% ; N$, number of adult trees per hectare; $D n$, mean diameter of the adult trees in $\mathrm{cm} ; \mathrm{H}$, mean height of adult trees in $\mathrm{m} ; \mathrm{G}$, basal area in $\mathrm{m}^{2} \mathrm{ha}^{-1} ; N s e$, number of seedlings per hectare; Nsa, number of saplings per hectare; ShCov, shrub coverage in \%. Rtree, number of tree species; and Rshrub, number of shrub species

Table 8 Stand attributes for the regions of provenance of Pinus pinea. Standard deviation between brackets

\begin{tabular}{|c|c|c|c|c|c|c|c|c|c|c|}
\hline Prov & $n$ & $N$ & $D n$ & $H t$ & $G$ & Nse & $N s a$ & ShCov & Rtree & Rshrub \\
\hline 1 & 383 & $\begin{array}{l}241 \\
(267)\end{array}$ & $\begin{array}{l}29 \\
(10.4)\end{array}$ & $\begin{array}{l}8.6 \\
(2.5)\end{array}$ & $\begin{array}{l}12 \\
(6.9)\end{array}$ & $\begin{array}{l}2278 \\
(2670)\end{array}$ & $\begin{array}{l}206 \\
(580)\end{array}$ & $\begin{array}{l}16.3 \\
(19.9)\end{array}$ & $\begin{array}{l}2 \\
(1)\end{array}$ & $\begin{array}{l}3 \\
(2)\end{array}$ \\
\hline 2 & 176 & $\begin{array}{l}160 \\
(157)\end{array}$ & $\begin{array}{l}35.6 \\
(15.7)\end{array}$ & $\begin{array}{l}9.6 \\
(3.3)\end{array}$ & $\begin{array}{l}12 \\
(7.6)\end{array}$ & $\begin{array}{l}3103 \\
(2157)\end{array}$ & $\begin{array}{l}177 \\
(360)\end{array}$ & $\begin{array}{l}43.7 \\
(33.4)\end{array}$ & $\begin{array}{l}2 \\
(1)\end{array}$ & $\begin{array}{l}4 \\
(2)\end{array}$ \\
\hline 3 & 54 & $\begin{array}{l}328 \\
(232)\end{array}$ & $\begin{array}{l}22.7 \\
(8.2)\end{array}$ & $\begin{array}{l}7.8 \\
(1.8)\end{array}$ & $\begin{array}{l}10.7 \\
(5.7)\end{array}$ & $\begin{array}{l}2986 \\
(2300)\end{array}$ & $\begin{array}{l}378 \\
(696)\end{array}$ & $\begin{array}{l}48.3 \\
(42.9)\end{array}$ & $\begin{array}{l}2 \\
(1)\end{array}$ & $\begin{array}{l}5 \\
(3)\end{array}$ \\
\hline 4 & 423 & $\begin{array}{l}232 \\
(211)\end{array}$ & $\begin{array}{l}24.8 \\
(9.8)\end{array}$ & $\begin{array}{l}8.9 \\
(3.6)\end{array}$ & $\begin{array}{l}9.5 \\
(6.7)\end{array}$ & $\begin{array}{l}1655 \\
(1879)\end{array}$ & $\begin{array}{l}78 \\
(261)\end{array}$ & $\begin{array}{l}53 \\
(36.7)\end{array}$ & $\begin{array}{l}2 \\
(1)\end{array}$ & $\begin{array}{l}6 \\
(3)\end{array}$ \\
\hline 5 & 314 & $\begin{array}{l}344 \\
(344)\end{array}$ & $\begin{array}{l}23.3 \\
(9)\end{array}$ & $\begin{array}{l}8.3 \\
(2.7)\end{array}$ & $\begin{array}{l}11.3 \\
(8.1)\end{array}$ & $\begin{array}{l}1804 \\
(2009)\end{array}$ & $\begin{array}{l}131 \\
(330)\end{array}$ & $\begin{array}{l}48.1 \\
(35.5)\end{array}$ & $\begin{array}{l}2 \\
(1)\end{array}$ & $\begin{array}{l}5 \\
(3)\end{array}$ \\
\hline 6 & 104 & $\begin{array}{l}435 \\
(378)\end{array}$ & $\begin{array}{l}25 \\
(7.6)\end{array}$ & $\begin{array}{l}9.4 \\
(2.6)\end{array}$ & $\begin{array}{l}18.7 \\
(13.2)\end{array}$ & $\begin{array}{l}4927 \\
(3355)\end{array}$ & $\begin{array}{l}593 \\
(850)\end{array}$ & $\begin{array}{l}63.8 \\
(36.4)\end{array}$ & $\begin{array}{l}2 \\
(1)\end{array}$ & $\begin{array}{l}8 \\
(3)\end{array}$ \\
\hline
\end{tabular}

Prov, region of provenance; $n$ number of plots with basal area of $P$. pinea larger than $80 \% ; N$, number of adult trees per hectare; $D n$, mean diameter of the adult trees in $\mathrm{cm} ; H$, mean height of adult trees in $\mathrm{m} ; G$, basal area in $\mathrm{m}^{2} \mathrm{ha}^{-1} ;$ Nse, number of seedlings per hectare; $N s a$, number of saplings per hectare; ShCov, shrub coverage in \%. Rtree, number of tree species; and Rshrub, number of shrub species 
Table 9 Stand attributes for the regions of provenance of Pinus halepensis. Standard deviation between brackets

\begin{tabular}{|c|c|c|c|c|c|c|c|c|c|c|}
\hline Prov & $n$ & $N$ & $D n$ & $H t$ & $G$ & Nse & Nsa & ShCov & Rtree & Rshrub \\
\hline 1 & 115 & $\begin{array}{l}777 \\
(480)\end{array}$ & $\begin{array}{l}18.2 \\
(5.4)\end{array}$ & $\begin{array}{l}10.7 \\
(2.2)\end{array}$ & $\begin{array}{l}18.9 \\
(9.1)\end{array}$ & $\begin{array}{l}7350 \\
(3962)\end{array}$ & $\begin{array}{l}928 \\
(908)\end{array}$ & $\begin{array}{l}96.9 \\
(44.2)\end{array}$ & $\begin{array}{l}2 \\
(1)\end{array}$ & $\begin{array}{l}10 \\
(3)\end{array}$ \\
\hline 2 & 271 & $\begin{array}{l}487 \\
(403)\end{array}$ & $\begin{array}{l}19 \\
(6.6)\end{array}$ & $\begin{array}{l}8.8 \\
(2.8)\end{array}$ & $\begin{array}{l}12.4 \\
(8.5)\end{array}$ & $\begin{array}{l}7031 \\
(3867)\end{array}$ & $\begin{array}{l}587 \\
(721)\end{array}$ & $\begin{array}{l}92.6 \\
(35.8)\end{array}$ & $\begin{array}{l}2 \\
(1)\end{array}$ & $\begin{array}{l}11 \\
(4)\end{array}$ \\
\hline 3 & 923 & $\begin{array}{l}456 \\
(379)\end{array}$ & $\begin{array}{l}18 \\
(5.8)\end{array}$ & $\begin{array}{l}8 \\
(2.5)\end{array}$ & $\begin{array}{l}10.9 \\
(8.2)\end{array}$ & $\begin{array}{l}6999 \\
(4901)\end{array}$ & $\begin{array}{l}630 \\
(808)\end{array}$ & $\begin{array}{l}87.2 \\
(34.5)\end{array}$ & $\begin{array}{l}2 \\
(1)\end{array}$ & $\begin{array}{l}10 \\
(4)\end{array}$ \\
\hline 4 & 219 & $\begin{array}{l}452 \\
(409)\end{array}$ & $\begin{array}{l}18.2 \\
(6.1)\end{array}$ & $\begin{array}{l}7.2 \\
(2)\end{array}$ & $\begin{array}{l}10.5 \\
(7.6)\end{array}$ & $\begin{array}{l}7791 \\
(5230)\end{array}$ & $\begin{array}{l}727 \\
(828)\end{array}$ & $\begin{array}{l}71.3 \\
(31.6)\end{array}$ & $\begin{array}{l}2 \\
(1)\end{array}$ & $\begin{array}{l}8 \\
(3)\end{array}$ \\
\hline 5 & 580 & $\begin{array}{l}406 \\
(383)\end{array}$ & $\begin{array}{l}17.7 \\
(5.4)\end{array}$ & $\begin{array}{l}7.2 \\
(1.8)\end{array}$ & $\begin{array}{l}8.8 \\
(7)\end{array}$ & $\begin{array}{l}5351 \\
(3709)\end{array}$ & $\begin{array}{l}520 \\
(687)\end{array}$ & $\begin{array}{l}68.9 \\
(30.3)\end{array}$ & $\begin{array}{l}2 \\
(1)\end{array}$ & $\begin{array}{l}8 \\
(4)\end{array}$ \\
\hline 6 & 413 & $\begin{array}{l}393 \\
(378)\end{array}$ & $\begin{array}{l}17.2 \\
(6.6)\end{array}$ & $\begin{array}{l}6.5 \\
(2.2)\end{array}$ & $\begin{array}{l}7.7 \\
(6.8)\end{array}$ & $\begin{array}{l}2854 \\
(2557)\end{array}$ & $\begin{array}{l}431 \\
(589)\end{array}$ & $\begin{array}{l}69.4 \\
(30.1)\end{array}$ & $\begin{array}{l}2 \\
(1)\end{array}$ & $\begin{array}{l}8 \\
(3)\end{array}$ \\
\hline 7 & 91 & $\begin{array}{l}346 \\
(296)\end{array}$ & $\begin{array}{l}21.1 \\
(9.0)\end{array}$ & $\begin{array}{l}8.1 \\
(2.4)\end{array}$ & $\begin{array}{l}9.8 \\
(6.7)\end{array}$ & $\begin{array}{l}5287 \\
(4005)\end{array}$ & $\begin{array}{l}489 \\
(652)\end{array}$ & $\begin{array}{l}60.5 \\
(28.1)\end{array}$ & $\begin{array}{l}2 \\
(1)\end{array}$ & $\begin{array}{l}6 \\
(2)\end{array}$ \\
\hline 8 & 76 & $\begin{array}{l}325 \\
(260)\end{array}$ & $\begin{array}{l}19.5 \\
(7.0)\end{array}$ & $\begin{array}{l}7.5 \\
(2)\end{array}$ & $\begin{array}{l}8.6 \\
(6.3)\end{array}$ & $\begin{array}{l}5645 \\
(3914)\end{array}$ & $\begin{array}{l}562 \\
(722)\end{array}$ & $\begin{array}{l}72.9 \\
(39.5)\end{array}$ & $\begin{array}{l}2 \\
(1)\end{array}$ & $\begin{array}{l}6 \\
(2)\end{array}$ \\
\hline 9 & 905 & $\begin{array}{l}347 \\
(333)\end{array}$ & $\begin{array}{l}20.3 \\
(6.9)\end{array}$ & $\begin{array}{l}9 \\
(2.5)\end{array}$ & $\begin{array}{l}9.7 \\
(7.6)\end{array}$ & $\begin{array}{l}5340 \\
(3535)\end{array}$ & $\begin{array}{l}423 \\
(788)\end{array}$ & $\begin{array}{l}77.3 \\
(34.9)\end{array}$ & $\begin{array}{l}2 \\
(1)\end{array}$ & $\begin{array}{l}8 \\
(3)\end{array}$ \\
\hline 10 & 1361 & $\begin{array}{l}322 \\
(295)\end{array}$ & $\begin{array}{l}19.2 \\
(7.0)\end{array}$ & $\begin{array}{l}7.8 \\
(2.3)\end{array}$ & $\begin{array}{l}7.7 \\
(5.9)\end{array}$ & $\begin{array}{l}3905 \\
(3093)\end{array}$ & $\begin{array}{l}336 \\
(590)\end{array}$ & $\begin{array}{l}70.6 \\
(31.5)\end{array}$ & $\begin{array}{l}2 \\
(1)\end{array}$ & $\begin{array}{l}9 \\
(3)\end{array}$ \\
\hline 11 & 184 & $\begin{array}{l}343 \\
(338)\end{array}$ & $\begin{array}{l}19.5 \\
(7.1)\end{array}$ & $\begin{array}{l}8.3 \\
(2.3)\end{array}$ & $\begin{array}{l}8.7 \\
(7.3)\end{array}$ & $\begin{array}{l}4473 \\
(3059)\end{array}$ & $\begin{array}{l}393 \\
(769)\end{array}$ & $\begin{array}{l}71.2 \\
(28.5)\end{array}$ & $\begin{array}{l}2 \\
(1)\end{array}$ & $\begin{array}{l}10 \\
(3)\end{array}$ \\
\hline 12 & 214 & $\begin{array}{l}312 \\
(233)\end{array}$ & $\begin{array}{l}21.4 \\
(7.4)\end{array}$ & $\begin{array}{l}8.8 \\
(2.4)\end{array}$ & $\begin{array}{l}10.4 \\
(6.5)\end{array}$ & $\begin{array}{l}4617 \\
(2413)\end{array}$ & $\begin{array}{l}494 \\
(559)\end{array}$ & $\begin{array}{l}95.5 \\
(36.2)\end{array}$ & $\begin{array}{l}2 \\
(1)\end{array}$ & $\begin{array}{l}5 \\
(2)\end{array}$ \\
\hline 13 & 206 & $\begin{array}{l}291 \\
(247)\end{array}$ & $\begin{array}{l}16 \\
(5)\end{array}$ & $\begin{array}{l}6.5 \\
(1.8)\end{array}$ & $\begin{array}{l}5.2 \\
(3.9)\end{array}$ & $\begin{array}{l}1123 \\
(1529)\end{array}$ & $\begin{array}{l}276 \\
(380)\end{array}$ & $\begin{array}{l}42.4 \\
(25.9)\end{array}$ & $\begin{array}{l}2 \\
(1)\end{array}$ & $\begin{array}{l}6 \\
(3)\end{array}$ \\
\hline 14 & 1789 & $\begin{array}{l}290 \\
(293)\end{array}$ & $\begin{array}{l}19.7 \\
(7.2)\end{array}$ & $\begin{array}{l}7.2 \\
(2.1)\end{array}$ & $\begin{array}{l}7.2 \\
(5.8)\end{array}$ & $\begin{array}{l}2554 \\
(2613)\end{array}$ & $\begin{array}{l}252 \\
(436)\end{array}$ & $\begin{array}{l}58.2 \\
(30.5)\end{array}$ & $\begin{array}{l}2 \\
(1)\end{array}$ & $\begin{array}{l}6 \\
(3)\end{array}$ \\
\hline 15 & 408 & $\begin{array}{l}320 \\
(278)\end{array}$ & $\begin{array}{l}19.6 \\
(8.4)\end{array}$ & $\begin{array}{l}6.9 \\
(2.3)\end{array}$ & $\begin{array}{l}8.3 \\
(6.3)\end{array}$ & $\begin{array}{l}2454 \\
(2568)\end{array}$ & $\begin{array}{l}330 \\
(589)\end{array}$ & $\begin{array}{l}31.2 \\
(22.1)\end{array}$ & $\begin{array}{l}2 \\
(1)\end{array}$ & $\begin{array}{l}5 \\
(3)\end{array}$ \\
\hline 16 & 95 & $\begin{array}{l}332 \\
(251)\end{array}$ & $\begin{array}{l}24 \\
(8.3)\end{array}$ & $\begin{array}{l}10.6 \\
(3.3)\end{array}$ & $\begin{array}{l}13.6 \\
(8)\end{array}$ & $\begin{array}{l}4884 \\
(3205)\end{array}$ & $\begin{array}{l}458 \\
(837)\end{array}$ & $\begin{array}{l}51.9 \\
(26.2)\end{array}$ & $\begin{array}{l}2 \\
(1)\end{array}$ & $\begin{array}{l}8 \\
(3)\end{array}$ \\
\hline 17 & 343 & $\begin{array}{l}393 \\
(366)\end{array}$ & $\begin{array}{l}21.5 \\
(8.5)\end{array}$ & $\begin{array}{l}8.5 \\
(3.1)\end{array}$ & $\begin{array}{l}11.4 \\
(8.5)\end{array}$ & $\begin{array}{l}2899 \\
(2520)\end{array}$ & $\begin{array}{l}258 \\
(569)\end{array}$ & $\begin{array}{l}48.4 \\
(28.8)\end{array}$ & $\begin{array}{l}2 \\
(1)\end{array}$ & $\begin{array}{l}7 \\
(3)\end{array}$ \\
\hline 18 & 323 & $\begin{array}{l}266 \\
(235)\end{array}$ & $\begin{array}{l}24.8 \\
(8.4)\end{array}$ & $\begin{array}{l}10.3 \\
(2.8)\end{array}$ & $\begin{array}{l}11.2 \\
(7.9)\end{array}$ & $\begin{array}{l}2755 \\
(2263)\end{array}$ & $\begin{array}{l}390 \\
(530)\end{array}$ & $\begin{array}{l}70.1 \\
(43)\end{array}$ & $\begin{array}{l}2 \\
(1)\end{array}$ & $\begin{array}{l}4 \\
(2)\end{array}$ \\
\hline 19 & 69 & $\begin{array}{l}521 \\
(452)\end{array}$ & $\begin{array}{l}14.9 \\
(4.8)\end{array}$ & $\begin{array}{l}6.1 \\
(1.8)\end{array}$ & $\begin{array}{l}8.5 \\
(7.6)\end{array}$ & $\begin{array}{l}1410 \\
(2003)\end{array}$ & $\begin{array}{l}458 \\
(786)\end{array}$ & $\begin{array}{l}38.1 \\
(28.6)\end{array}$ & $\begin{array}{l}2 \\
(1)\end{array}$ & $\begin{array}{l}4 \\
(2)\end{array}$ \\
\hline 20 & 64 & $\begin{array}{l}360 \\
(242)\end{array}$ & $\begin{array}{l}19.8 \\
(5.9)\end{array}$ & $\begin{array}{l}9 \\
(2)\end{array}$ & $\begin{array}{l}11.1 \\
(6.1)\end{array}$ & $\begin{array}{l}5859 \\
(3540)\end{array}$ & $\begin{array}{l}585 \\
(758)\end{array}$ & $\begin{array}{l}92.1 \\
(37)\end{array}$ & $\begin{array}{l}2 \\
(1)\end{array}$ & $\begin{array}{l}6 \\
(2)\end{array}$ \\
\hline
\end{tabular}

Prov, region of provenance; $n$, number of plots with basal area of $P$. halepensis larger than $80 \% ; N$, number of adult trees per hectare; Dn, mean diameter of the adult trees in $\mathrm{cm} ; \mathrm{H}$, mean height of adult trees in $\mathrm{m} ; G$, basal area in $\mathrm{m}^{2} \mathrm{ha}^{-1}$; Nse, number of seedlings per hectare; Nsa, number of saplings per hectare; ShCov, shrub coverage in \%. Rtree, number of tree species; and Rshrub, number of shrub species 
Table 10 Stand attributes for the regions of provenance of Quercus pyrenaica. Standard deviation between brackets

\begin{tabular}{|c|c|c|c|c|c|c|c|c|c|c|}
\hline Prov & $n$ & $N$ & $D n$ & $H t$ & $\mathrm{G}$ & Nse & Nsa & ShCov & Rtree & Rshrub \\
\hline 1 & 71 & $\begin{array}{l}437 \\
(458)\end{array}$ & $\begin{array}{l}21.5 \\
(11.9)\end{array}$ & $\begin{array}{l}10.1 \\
(3.6)\end{array}$ & $\begin{array}{l}13.2 \\
(11.1)\end{array}$ & $\begin{array}{l}3141 \\
(2162)\end{array}$ & $\begin{array}{l}625 \\
(910)\end{array}$ & $\begin{array}{l}91.3 \\
(46)\end{array}$ & $\begin{array}{l}2 \\
(1)\end{array}$ & $\begin{array}{l}4 \\
(2)\end{array}$ \\
\hline 10 & 225 & $\begin{array}{l}463 \\
(550)\end{array}$ & $\begin{array}{l}24.7 \\
(16.5)\end{array}$ & $\begin{array}{l}10.2 \\
(3.2)\end{array}$ & $\begin{array}{l}10 \\
(8.1)\end{array}$ & $\begin{array}{l}3407 \\
(2264)\end{array}$ & $\begin{array}{l}531 \\
(1026)\end{array}$ & $\begin{array}{l}36 \\
(33.9)\end{array}$ & $\begin{array}{l}2 \\
(1)\end{array}$ & $\begin{array}{l}3 \\
(2)\end{array}$ \\
\hline 11 & 40 & $\begin{array}{l}435 \\
(519)\end{array}$ & $\begin{array}{l}20.6 \\
(18.6)\end{array}$ & $\begin{array}{l}7.7 \\
(2.4)\end{array}$ & $\begin{array}{l}6.3 \\
(6.2)\end{array}$ & $\begin{array}{l}3136 \\
(2652)\end{array}$ & $\begin{array}{l}796 \\
(1363)\end{array}$ & $\begin{array}{l}35.2 \\
(31.5)\end{array}$ & $\begin{array}{l}2 \\
(1)\end{array}$ & $\begin{array}{l}3 \\
(2)\end{array}$ \\
\hline 12 & 203 & $\begin{array}{l}708 \\
(811)\end{array}$ & $\begin{array}{l}15.9 \\
(12.1)\end{array}$ & $\begin{array}{l}7.8 \\
(2.2)\end{array}$ & $\begin{array}{l}9.9 \\
(9.3)\end{array}$ & $\begin{array}{l}4062 \\
(2546)\end{array}$ & $\begin{array}{l}901 \\
(1298)\end{array}$ & $\begin{array}{l}40 \\
(35.2)\end{array}$ & $\begin{array}{l}2 \\
(1)\end{array}$ & $\begin{array}{l}3 \\
(2)\end{array}$ \\
\hline 13 & 29 & $\begin{array}{l}766 \\
(634)\end{array}$ & $\begin{array}{l}11 \\
(2.3)\end{array}$ & $\begin{array}{l}6 \\
(1.3)\end{array}$ & $\begin{array}{l}7.5 \\
(6.9)\end{array}$ & $\begin{array}{l}5871 \\
(1881)\end{array}$ & $\begin{array}{l}984 \\
(1116)\end{array}$ & $\begin{array}{l}55.3 \\
(36.3)\end{array}$ & $\begin{array}{l}2 \\
(1)\end{array}$ & $\begin{array}{l}3 \\
(2)\end{array}$ \\
\hline 14 & 61 & $\begin{array}{l}555 \\
(546)\end{array}$ & $\begin{array}{l}18.4 \\
(9.8)\end{array}$ & $\begin{array}{l}8.3 \\
(2.6)\end{array}$ & $\begin{array}{l}9.8 \\
(7.1)\end{array}$ & $\begin{array}{l}3900 \\
(2386)\end{array}$ & $\begin{array}{l}387 \\
(762)\end{array}$ & $\begin{array}{l}27.6 \\
(26.5)\end{array}$ & $\begin{array}{l}2 \\
(1)\end{array}$ & $\begin{array}{l}3 \\
(3)\end{array}$ \\
\hline 2 & 135 & $\begin{array}{l}610 \\
(729)\end{array}$ & $\begin{array}{l}18.8 \\
(10.9)\end{array}$ & $\begin{array}{l}9.4 \\
(3.3)\end{array}$ & $\begin{array}{l}11.7 \\
(10.8)\end{array}$ & $\begin{array}{l}3384 \\
(2402)\end{array}$ & $\begin{array}{l}915 \\
(1319)\end{array}$ & $\begin{array}{l}65.1 \\
(42.6)\end{array}$ & $\begin{array}{l}2 \\
(1)\end{array}$ & $\begin{array}{l}4 \\
(2)\end{array}$ \\
\hline 3 & 183 & $\begin{array}{l}428 \\
(438)\end{array}$ & $\begin{array}{l}17.5 \\
(8.6)\end{array}$ & $\begin{array}{l}8.6 \\
(2.8)\end{array}$ & $\begin{array}{l}7.8 \\
(7.0)\end{array}$ & $\begin{array}{l}3789 \\
(2201)\end{array}$ & $\begin{array}{l}863 \\
(1312)\end{array}$ & $\begin{array}{l}59.2 \\
(32.4)\end{array}$ & $\begin{array}{l}2 \\
(1)\end{array}$ & $\begin{array}{l}5 \\
(2)\end{array}$ \\
\hline 4 & 446 & $\begin{array}{l}661 \\
(618)\end{array}$ & $\begin{array}{l}14.9 \\
(9.3)\end{array}$ & $\begin{array}{l}7.6 \\
(2.2)\end{array}$ & $\begin{array}{l}9.8 \\
(9.5)\end{array}$ & $\begin{array}{l}5024 \\
(2444)\end{array}$ & $\begin{array}{l}1632 \\
(1919)\end{array}$ & $\begin{array}{l}55.8 \\
(36.8)\end{array}$ & $\begin{array}{l}2 \\
(1)\end{array}$ & $\begin{array}{l}4 \\
(2)\end{array}$ \\
\hline 5 & 181 & $\begin{array}{l}765 \\
(710)\end{array}$ & $\begin{array}{l}18.8 \\
(9.4)\end{array}$ & $\begin{array}{l}9.7 \\
(3.5)\end{array}$ & $\begin{array}{l}16.9 \\
(12.2)\end{array}$ & $\begin{array}{l}5623 \\
(3539)\end{array}$ & $\begin{array}{l}856 \\
(1235)\end{array}$ & $\begin{array}{l}58.4 \\
(32)\end{array}$ & $\begin{array}{l}2 \\
(1)\end{array}$ & $\begin{array}{l}5 \\
(2)\end{array}$ \\
\hline 6 & 479 & $\begin{array}{l}847 \\
(708)\end{array}$ & $\begin{array}{l}16.9 \\
(11.6)\end{array}$ & $\begin{array}{l}8.4 \\
(2.5)\end{array}$ & $\begin{array}{l}14.6 \\
(10.8)\end{array}$ & $\begin{array}{l}5552 \\
(3098)\end{array}$ & $\begin{array}{l}1149 \\
(1359)\end{array}$ & $\begin{array}{l}55.4 \\
(36.9)\end{array}$ & $\begin{array}{l}2 \\
(1)\end{array}$ & $\begin{array}{l}4 \\
(2)\end{array}$ \\
\hline 7 & 141 & $\begin{array}{l}114 \\
(290)\end{array}$ & $\begin{array}{l}36.1 \\
(16)\end{array}$ & $\begin{array}{l}8.4 \\
(2.2)\end{array}$ & $\begin{array}{l}4.6 \\
(4.0)\end{array}$ & $\begin{array}{l}2480 \\
(2474)\end{array}$ & $\begin{array}{l}94 \\
(274)\end{array}$ & $\begin{array}{l}24.5 \\
(27.7)\end{array}$ & $\begin{array}{l}2 \\
(1)\end{array}$ & $\begin{array}{l}2 \\
(2)\end{array}$ \\
\hline 8 & 314 & $\begin{array}{l}633 \\
(617)\end{array}$ & $\begin{array}{l}17.7 \\
(10.2)\end{array}$ & $\begin{array}{l}9.1 \\
(2.9)\end{array}$ & $\begin{array}{l}10.7 \\
(8.0)\end{array}$ & $\begin{array}{l}3837 \\
(2090)\end{array}$ & $\begin{array}{l}615 \\
(1094)\end{array}$ & $\begin{array}{l}30.9 \\
(27.4)\end{array}$ & $\begin{array}{l}2 \\
(1)\end{array}$ & $\begin{array}{l}3 \\
(2)\end{array}$ \\
\hline 9 & 116 & $\begin{array}{l}449 \\
(547)\end{array}$ & $\begin{array}{l}24.6 \\
(16.3)\end{array}$ & $\begin{array}{l}9.5 \\
(2.7)\end{array}$ & $\begin{array}{l}11.3 \\
(8.8)\end{array}$ & $\begin{array}{l}2642 \\
(2168)\end{array}$ & $\begin{array}{l}313 \\
(609)\end{array}$ & $\begin{array}{l}30.6 \\
(26.8)\end{array}$ & $\begin{array}{l}2 \\
(1)\end{array}$ & $\begin{array}{l}3 \\
(2)\end{array}$ \\
\hline $\mathrm{C}$ & 39 & $\begin{array}{l}439 \\
(649)\end{array}$ & $\begin{array}{l}20.9 \\
(10.6)\end{array}$ & $\begin{array}{l}8.7 \\
(3)\end{array}$ & $\begin{array}{l}10.5 \\
(12.6)\end{array}$ & $\begin{array}{l}3997 \\
(2927)\end{array}$ & $\begin{array}{l}624 \\
(1049)\end{array}$ & $\begin{array}{l}56.1 \\
(40.1)\end{array}$ & $\begin{array}{l}2 \\
(1)\end{array}$ & $\begin{array}{l}4 \\
(2)\end{array}$ \\
\hline $\mathrm{D}$ & 84 & $\begin{array}{l}414 \\
(374)\end{array}$ & $\begin{array}{l}27.5 \\
(16.9)\end{array}$ & $\begin{array}{l}8.6 \\
(2.6)\end{array}$ & $\begin{array}{l}16.3 \\
(11.1)\end{array}$ & $\begin{array}{l}3214 \\
(2559)\end{array}$ & $\begin{array}{l}563 \\
(995)\end{array}$ & $\begin{array}{l}59 \\
(35.3)\end{array}$ & $\begin{array}{l}2 \\
(1)\end{array}$ & $\begin{array}{l}4 \\
(2)\end{array}$ \\
\hline
\end{tabular}

Prov, region of provenance; $n$, number of plots with basal area of $Q$. pyrenaica larger than $80 \% ; N$, number of adult trees per hectare; Dn, mean diameter of the adult trees in $\mathrm{cm} ; H$, mean height of adult trees in $\mathrm{m} ; G$, basal area in $\mathrm{m}^{2} \mathrm{ha}^{-1} ; N s e$, number of seedlings per hectare; Nsa, number of saplings per hectare; ShCov, shrub coverage in \%. Rtree, number of tree species; and Rshrub, number of shrub species 
Table 11 Stand attributes for the regions of provenance of Quercus faginea. Standard deviation between brackets

\begin{tabular}{|c|c|c|c|c|c|c|c|c|c|c|}
\hline Prov & $n$ & $N$ & $D n$ & $H t$ & $G$ & Nse & Nsa & ShCov & Rtree & Rshrub \\
\hline 1 & 390 & $\begin{array}{l}631 \\
(687)\end{array}$ & $\begin{array}{l}18.3 \\
(13.5)\end{array}$ & $\begin{array}{l}7.2 \\
(2.6)\end{array}$ & $\begin{array}{l}11.2 \\
(10.5)\end{array}$ & $\begin{array}{l}1315 \\
(1459)\end{array}$ & $\begin{array}{l}1315 \\
(1459)\end{array}$ & $\begin{array}{l}60.1 \\
(34.2)\end{array}$ & $\begin{array}{l}2 \\
(1)\end{array}$ & $\begin{array}{l}6 \\
(3)\end{array}$ \\
\hline 10 & 173 & $\begin{array}{l}527 \\
(570)\end{array}$ & $\begin{array}{l}14.3 \\
(9.7)\end{array}$ & $\begin{array}{l}6.3 \\
(1.7)\end{array}$ & $\begin{array}{l}5.9 \\
(5.2)\end{array}$ & $\begin{array}{l}1088 \\
(1458)\end{array}$ & $\begin{array}{l}1088 \\
(1458)\end{array}$ & $\begin{array}{l}49.8 \\
(30.4)\end{array}$ & $\begin{array}{l}2 \\
\text { (1) }\end{array}$ & $\begin{array}{l}5 \\
\text { (2) }\end{array}$ \\
\hline 11 & 46 & $\begin{array}{l}623 \\
(643)\end{array}$ & $\begin{array}{l}13.3 \\
(5.1)\end{array}$ & $\begin{array}{l}6 \\
(1.7)\end{array}$ & $\begin{array}{l}7.3 \\
(6)\end{array}$ & $\begin{array}{l}1423 \\
(1454)\end{array}$ & $\begin{array}{l}1423 \\
(1454)\end{array}$ & $\begin{array}{l}41.5 \\
(28.9)\end{array}$ & $\begin{array}{l}2 \\
(1)\end{array}$ & $\begin{array}{l}5 \\
(2)\end{array}$ \\
\hline 15 & 24 & $\begin{array}{l}233 \\
(291)\end{array}$ & $\begin{array}{l}21.5 \\
(13.9)\end{array}$ & $\begin{array}{l}7.6 \\
(2.3)\end{array}$ & $\begin{array}{l}3.8 \\
(3.4)\end{array}$ & $\begin{array}{l}260 \\
(344)\end{array}$ & $\begin{array}{l}260 \\
(344)\end{array}$ & $\begin{array}{l}50.2 \\
(43.2)\end{array}$ & $\begin{array}{l}2 \\
\text { (1) }\end{array}$ & $\begin{array}{l}6 \\
\text { (4) }\end{array}$ \\
\hline 18 & 21 & $\begin{array}{l}75 \\
(104)\end{array}$ & $\begin{array}{l}49.9 \\
(28.4)\end{array}$ & $\begin{array}{l}9.4 \\
(2.1)\end{array}$ & $\begin{array}{l}8.9 \\
(4.4)\end{array}$ & $\begin{array}{l}231 \\
(371)\end{array}$ & $\begin{array}{l}231 \\
(371)\end{array}$ & $\begin{array}{l}69.6 \\
(44.1)\end{array}$ & $\begin{array}{l}2 \\
\text { (1) }\end{array}$ & $\begin{array}{l}9 \\
(4)\end{array}$ \\
\hline 2 & 260 & $\begin{array}{l}615 \\
(597)\end{array}$ & $\begin{array}{l}17.1 \\
(12.3)\end{array}$ & $\begin{array}{l}6.6 \\
(2.2)\end{array}$ & $\begin{array}{l}10.1 \\
(9)\end{array}$ & $\begin{array}{l}940 \\
(1237)\end{array}$ & $\begin{array}{l}940 \\
(1237)\end{array}$ & $\begin{array}{l}48.4 \\
(30.3)\end{array}$ & $\begin{array}{l}2 \\
\text { (1) }\end{array}$ & $\begin{array}{l}5 \\
\text { (3) }\end{array}$ \\
\hline 3 & 27 & $\begin{array}{l}580 \\
(502)\end{array}$ & $\begin{array}{l}16.4 \\
(8)\end{array}$ & $\begin{array}{l}8.7 \\
(3.4)\end{array}$ & $\begin{array}{l}8.1 \\
(6.1)\end{array}$ & $\begin{array}{l}717 \\
(768)\end{array}$ & $\begin{array}{l}717 \\
(768)\end{array}$ & $\begin{array}{l}50.6 \\
(29.2)\end{array}$ & $\begin{array}{l}2 \\
(1)\end{array}$ & $\begin{array}{l}6 \\
(3)\end{array}$ \\
\hline 6 & 42 & $\begin{array}{l}57 \\
(116)\end{array}$ & $\begin{array}{l}46.5 \\
(16.5)\end{array}$ & $\begin{array}{l}8.5 \\
(2.5)\end{array}$ & $\begin{array}{l}4.6 \\
(2.9)\end{array}$ & $\begin{array}{l}143 \\
(474)\end{array}$ & $\begin{array}{l}143 \\
(474)\end{array}$ & $\begin{array}{l}12 \\
(23.7)\end{array}$ & $\begin{array}{l}2 \\
\text { (1) }\end{array}$ & $\begin{array}{l}2 \\
(2)\end{array}$ \\
\hline 7 & 126 & $\begin{array}{l}393 \\
(376)\end{array}$ & $\begin{array}{l}13.5 \\
(8.8)\end{array}$ & $\begin{array}{l}5.4 \\
(1.5)\end{array}$ & $\begin{array}{l}4.9 \\
(5.3)\end{array}$ & $\begin{array}{l}1361 \\
(1442)\end{array}$ & $\begin{array}{l}1361 \\
(1442)\end{array}$ & $\begin{array}{l}34.5 \\
(22.1)\end{array}$ & $\begin{array}{l}2 \\
\text { (1) }\end{array}$ & $\begin{array}{l}4 \\
\text { (2) }\end{array}$ \\
\hline 8 & 46 & $\begin{array}{l}564 \\
(404)\end{array}$ & $\begin{array}{l}12.9 \\
(7.7)\end{array}$ & $\begin{array}{l}5.6 \\
(1.6)\end{array}$ & $\begin{array}{l}6.1 \\
(4.6)\end{array}$ & $\begin{array}{l}1401 \\
(1308)\end{array}$ & $\begin{array}{l}1401 \\
(1308)\end{array}$ & $\begin{array}{l}47.6 \\
(30.4)\end{array}$ & $\begin{array}{l}2 \\
\text { (1) }\end{array}$ & $\begin{array}{l}4 \\
(2)\end{array}$ \\
\hline 9 & 73 & $\begin{array}{l}520 \\
(606)\end{array}$ & $\begin{array}{l}11.4 \\
(3.7)\end{array}$ & $\begin{array}{l}5.1 \\
(1.3)\end{array}$ & $\begin{array}{l}4.7 \\
(5.1)\end{array}$ & $\begin{array}{l}1640 \\
(1594)\end{array}$ & $\begin{array}{l}1640 \\
(1594)\end{array}$ & $\begin{array}{l}50 \\
(30.9)\end{array}$ & $\begin{array}{l}2 \\
\text { (1) }\end{array}$ & $\begin{array}{l}4 \\
\text { (2) }\end{array}$ \\
\hline A & 40 & $\begin{array}{l}613 \\
(630)\end{array}$ & $\begin{array}{l}18.4 \\
(14.3)\end{array}$ & $\begin{array}{l}7.3 \\
(2.2)\end{array}$ & $\begin{array}{l}10.4 \\
(8)\end{array}$ & $\begin{array}{l}1121 \\
(1063)\end{array}$ & $\begin{array}{l}1121 \\
(1063)\end{array}$ & $\begin{array}{l}40.8 \\
(22.7)\end{array}$ & $\begin{array}{l}2 \\
(1)\end{array}$ & $\begin{array}{l}4 \\
(2)\end{array}$ \\
\hline
\end{tabular}

Prov, region of provenance; $n$, number of plots with basal area of $Q$. faginea larger than $80 \% ; N$, number of adult trees per hectare; $D n$, mean diameter of the adult trees in $\mathrm{cm} ; \mathrm{H}$, mean height of adult trees in $\mathrm{m} ; G$, basal area in $\mathrm{m}^{2} \mathrm{ha}^{-1} ;$ Nse, number of seedlings per hectare; Nsa, number of saplings per hectare; ShCov, shrub coverage in \%. Rtree, number of tree species; and Rshrub, number of shrub species

Table 12 Stand attributes for the regions of provenance of Quercus suber. Standard deviation between brackets

\begin{tabular}{|c|c|c|c|c|c|c|c|c|c|c|}
\hline Prov & $n$ & $N$ & $D n$ & $H t$ & G & Nse & Nsa & ShCov & Rtree & Rshrub \\
\hline 1 & 49 & $\begin{array}{l}79 \\
(4)\end{array}$ & $\begin{array}{l}41.2 \\
(16.6)\end{array}$ & $\begin{array}{l}8.4 \\
(2)\end{array}$ & $\begin{array}{l}8.1 \\
(5.2)\end{array}$ & $\begin{array}{l}2175 \\
(3251)\end{array}$ & $\begin{array}{l}195 \\
(760)\end{array}$ & $\begin{array}{l}41.8 \\
(46.6)\end{array}$ & $\begin{array}{l}2 \\
(1)\end{array}$ & $\begin{array}{l}4 \\
(3)\end{array}$ \\
\hline 2 & 170 & $\begin{array}{l}97 \\
(5)\end{array}$ & $\begin{array}{l}37.8 \\
(14.6)\end{array}$ & $\begin{array}{l}7.5 \\
(1.7)\end{array}$ & $\begin{array}{l}7.7 \\
(5.0)\end{array}$ & $\begin{array}{l}1894 \\
(2130)\end{array}$ & $\begin{array}{l}129 \\
(468)\end{array}$ & $\begin{array}{l}48.2 \\
(39.1)\end{array}$ & $\begin{array}{l}2 \\
(1)\end{array}$ & $\begin{array}{l}5 \\
(3)\end{array}$ \\
\hline 3 & 79 & $\begin{array}{l}114 \\
(6)\end{array}$ & $\begin{array}{l}34.9 \\
(17.4)\end{array}$ & $\begin{array}{l}7.9 \\
(2.1)\end{array}$ & $\begin{array}{l}7 \\
(5.7)\end{array}$ & $\begin{array}{l}3609 \\
(3695)\end{array}$ & $\begin{array}{l}373 \\
(736)\end{array}$ & $\begin{array}{l}68.4 \\
(44)\end{array}$ & $\begin{array}{l}2 \\
(1)\end{array}$ & $\begin{array}{l}6 \\
(4)\end{array}$ \\
\hline 4 & 21 & $\begin{array}{l}73 \\
(7)\end{array}$ & $\begin{array}{l}25.9 \\
(9.1)\end{array}$ & $\begin{array}{l}5.9 \\
(1.2)\end{array}$ & $\begin{array}{l}3 \\
(3.7)\end{array}$ & $\begin{array}{l}4499 \\
(4233)\end{array}$ & $\begin{array}{l}55 \\
(104)\end{array}$ & $\begin{array}{l}90 \\
(37.2)\end{array}$ & $\begin{array}{l}2 \\
(1)\end{array}$ & $\begin{array}{l}7 \\
(4)\end{array}$ \\
\hline 5 & 300 & $\begin{array}{l}121 \\
(6)\end{array}$ & $\begin{array}{l}34.6 \\
(15.2)\end{array}$ & $\begin{array}{l}7.9 \\
(2.2)\end{array}$ & $\begin{array}{l}8.3 \\
(5.7)\end{array}$ & $\begin{array}{l}3428 \\
(3475)\end{array}$ & $\begin{array}{l}120 \\
(404)\end{array}$ & $\begin{array}{l}54.1 \\
(47.6)\end{array}$ & $\begin{array}{l}2 \\
(1)\end{array}$ & $\begin{array}{l}6 \\
(4)\end{array}$ \\
\hline 7 & 480 & $\begin{array}{l}207 \\
(8)\end{array}$ & $\begin{array}{l}33.3 \\
(13.1)\end{array}$ & $\begin{array}{l}8.2 \\
(2.4)\end{array}$ & $\begin{array}{l}14.3 \\
(8.8)\end{array}$ & $\begin{array}{l}4057 \\
(3193)\end{array}$ & $\begin{array}{l}85 \\
(273)\end{array}$ & $\begin{array}{l}70.2 \\
(40.9)\end{array}$ & $\begin{array}{l}2 \\
(1)\end{array}$ & $\begin{array}{l}8 \\
(3)\end{array}$ \\
\hline 8 & 84 & $\begin{array}{l}594 \\
(7)\end{array}$ & $\begin{array}{l}19.5 \\
(6.4)\end{array}$ & $\begin{array}{l}6.5 \\
(1.5)\end{array}$ & $\begin{array}{l}16.2 \\
(9.3)\end{array}$ & $\begin{array}{l}4595 \\
(3044)\end{array}$ & $\begin{array}{l}425 \\
(486)\end{array}$ & $\begin{array}{l}83 \\
(25.6)\end{array}$ & $\begin{array}{l}2 \\
(1)\end{array}$ & $\begin{array}{l}7 \\
(2)\end{array}$ \\
\hline 9 & 224 & $\begin{array}{l}609 \\
(8)\end{array}$ & $18(5)$ & $\begin{array}{l}6.4 \\
(1.6)\end{array}$ & $\begin{array}{l}14.8 \\
(9.4)\end{array}$ & $\begin{array}{l}5772 \\
(4460)\end{array}$ & $\begin{array}{l}861 \\
(1047)\end{array}$ & $\begin{array}{l}97.4 \\
(38.7)\end{array}$ & $\begin{array}{l}2 \\
(1)\end{array}$ & $\begin{array}{l}8 \\
(3)\end{array}$ \\
\hline $\mathrm{H}$ & 40 & $\begin{array}{l}344 \\
(10)\end{array}$ & $\begin{array}{l}25.1 \\
(19)\end{array}$ & $\begin{array}{l}6.3 \\
(1.9)\end{array}$ & $\begin{array}{l}11.1 \\
(7.7)\end{array}$ & $\begin{array}{l}7013 \\
(3883)\end{array}$ & $\begin{array}{l}510 \\
(1037)\end{array}$ & $\begin{array}{l}79 \\
(35.8)\end{array}$ & $\begin{array}{l}2 \\
(1)\end{array}$ & $\begin{array}{l}10 \\
(5)\end{array}$ \\
\hline
\end{tabular}

Prov, region of provenance; $n$, number of plots with basal area of $Q$. suber larger than $80 \% ; N$, number of adult trees per hectare; Dn, mean diameter of the adult trees in cm; $H$, mean height of adult trees in $\mathrm{m} ; G$, basal area in $\mathrm{m}^{2} \mathrm{ha}^{-1}$; Nse, number of seedlings per hectare; $N s a$, number of saplings per hectare; ShCov, shrub coverage in \%. Rtree, number of tree species; and Rshrub, number of shrub species 
Table 13 Stand attributes for the regions of provenance of Quercus suber. Standard deviation between brackets

\begin{tabular}{|c|c|c|c|c|c|c|c|c|c|c|}
\hline Prov & $n$ & $N$ & $D n$ & $H t$ & $G$ & Nse & $N s a$ & ShCov & Rtree & Rshrub \\
\hline \multirow[t]{2}{*}{1} & \multirow[t]{2}{*}{634} & 161 & 34.4 & 6.4 & 6.1 & 333 & 333 & 37.9 & 2 & 3 \\
\hline & & $(252)$ & 21.1) & (1.7) & $(4.2)$ & (694) & 694) & 37.9) & (1) & (3) \\
\hline \multirow[t]{2}{*}{10} & \multirow[t]{2}{*}{525} & 624 & 12.6 & 4.7 & 6.6 & 1984 & 1984 & 47.4 & 2 & 6 \\
\hline & & $(586)$ & $6.1)$ & (1.1) & $(6.2)$ & (2212) & 2212) & 29.8) & (1) & (3) \\
\hline \multirow[t]{2}{*}{11} & 48 & 109 & 33.6 & 6.7 & 5 & 170 & 170 & 25.3 & 2 & 3 \\
\hline & 1 & (185) & 16.3) & (1.7) & $(3.3)$ & (537) & 537) & 33) & (1) & (3) \\
\hline \multirow[t]{2}{*}{12} & \multirow[t]{2}{*}{318} & 358 & 15.3 & 4.9 & 4 & 1147 & 1147 & 46.7 & 2 & 4 \\
\hline & & (473) & 10.4) & (1.5) & $(5.1)$ & (1512) & 1512) & 32.9) & (1) & (3) \\
\hline \multirow[t]{2}{*}{13} & \multirow[t]{2}{*}{212} & 177 & 32.4 & 6.6 & 5.9 & 291 & 291 & 44.8 & 2 & 6 \\
\hline & & $(340)$ & 18.7) & (1.8) & $(4.7)$ & (689) & 689) & $34.5)$ & (1) & (4) \\
\hline \multirow[t]{2}{*}{14} & \multirow[t]{2}{*}{197} & 339 & 16.3 & 5.1 & 4.5 & 753 & 753 & 48.8 & 2 & 6 \\
\hline & & $(380)$ & 7.8) & (1.3) & $(4.1)$ & (1089) & 1089) & 40.3) & (1) & (4) \\
\hline \multirow[t]{2}{*}{15} & \multirow[t]{2}{*}{162} & 436 & 14.1 & 4.6 & 5.5 & 1207 & 1207 & 30.8 & 2 & 5 \\
\hline & & (459) & $5.3)$ & (1.1) & (4.9) & (1479) & 1479) & 22) & (1) & (3) \\
\hline \multirow[t]{2}{*}{16} & \multirow[t]{2}{*}{153} & 455 & 15.2 & 4.8 & 5.8 & 1161 & 1161 & 40.2 & 2 & 5 \\
\hline & & $(507)$ & 10.1) & (1.4) & (5.3) & (1454) & 1454) & 24.8) & (1) & (3) \\
\hline \multirow[t]{2}{*}{17} & \multirow[t]{2}{*}{67} & 789 & 17.5 & 6.7 & 16.3 & 658 & 658 & 26 & 2 & 3 \\
\hline & & (631) & $6.2)$ & (1.6) & $(8.7)$ & (841) & 841) & 32.1) & (1) & (2) \\
\hline \multirow[t]{2}{*}{2} & \multirow[t]{2}{*}{291} & 526 & 16.6 & 5.1 & 6.1 & 1804 & 1804 & 34 & 2 & 4 \\
\hline & & $(645)$ & 12.7) & (1.3) & $(5.8)$ & (2147) & 2147) & 27) & (1) & (2) \\
\hline \multirow[t]{2}{*}{3} & 518 & 917 & 13.5 & 5.1 & 12.1 & 2101 & 2101 & 53.1 & 2 & 5 \\
\hline & & $(742)$ & 7.4) & (1.3) & $(9.8)$ & (1992) & 1992) & 34.6) & (1) & (3) \\
\hline 4 & 461 & 704 & 12.7 & 4.9 & 7.6 & 1661 & 1661 & 47.6 & 2 & 5 \\
\hline & & $(690)$ & 4.8) & (1.2) & $(7.2)$ & (1753) & 1753) & 28.4) & (1) & (2) \\
\hline 5 & 543 & 1277 & 13.1 & 6.8 & 16.6 & 2039 & 2039 & 69.6 & 2 & 7 \\
\hline & & (792) & 3.7) & (1.7) & $(9.1)$ & (1642) & 1642) & 46.8) & (1) & (3) \\
\hline 6 & 77 & 1028 & 12.1 & 4.9 & 10.7 & 2535 & 2535 & 83.4 & 2 & 8 \\
\hline & & $(792)$ & 4.3) & (1) & $(7.8)$ & (1994) & 1994) & 43.8) & (1) & (4) \\
\hline 7 & 448 & 171 & 33.8 & 6 & 6.1 & 491 & 491 & 24 & 2 & 3 \\
\hline & & (249) & 23.7) & (1.7) & $(4.5)$ & (897) & 897) & 23.7) & (1) & (2) \\
\hline 8 & 645 & 254 & 22.7 & 6 & 4.6 & 517 & 517 & 31.9 & 2 & 2 \\
\hline & & $(360)$ & $14.3)$ & (1.8) & (3.5) & (904) & 904) & 32.2) & (1) & (2) \\
\hline 9 & 340 & 569 & 12 & 4.9 & 5.4 & 1908 & 1908 & 49.9 & 2 & 5 \\
\hline & & (547) & $5.8)$ & (1.2) & (5.1) & (1813) & 1813) & 30.4) & (1) & (2) \\
\hline A & 22 & 390 & 16.1 & 6 & 6 & 822 & 822 & 87.6 & 2 & 6 \\
\hline & & $(570)$ & 7.6) & (1.6) & (8) & (1029) & 1029) & 44.7) & (1) & (3) \\
\hline $\mathrm{C}$ & 34 & 610 & 16.4 & 5.5 & 10.7 & 1045 & 1045 & (41) & 2 & 4 \\
\hline & & (609) & $6.2)$ & (1.5) & $(8.8)$ & (1106) & 1106) & 53.8 & (1) & (2) \\
\hline $\mathrm{D}$ & 40 & 831 & 18.4 & 6.9 & 12.2 & 2213 & 2213 & 39) & 2 & 4 \\
\hline & & (922) & $14.3)$ & (2) & (13) & (2646) & 2646) & 74.5 & (1) & (2) \\
\hline E & 26 & 1009 & 16.2 & 7.2 & 20 & 1186 & 1186 & 63.7) & 2 & 5 \\
\hline & & $(661)$ & 4.6) & (1.7) & 11.2) & (1426) & 1426) & 71.1 & (1) & (2) \\
\hline $\mathrm{J}$ & 34 & 576 & 12.1 & 4.7 & 6.9 & 1409 & 1409 & $30.5)$ & 2 & 8 \\
\hline & & $(590)$ & (3) & (1) & (7.6) & (1915) & 1915) & 84 & (1) & (3) \\
\hline K & 24 & 538 & 15.2 & 6.2 & 9.9 & 1253 & 1253 & 37.7) & 2 & 6 \\
\hline & & (337) & 4.6) & (1.6) & $(4.8)$ & (1502) & 1502) & 37.9 & (1) & (2) \\
\hline
\end{tabular}

Prov, region of provenance; $n$, number of plots with basal area of $Q$. ilex larger than $80 \% ; N$, number of adult trees per hectare; $D n$, mean diameter of the adult trees in cm; $H$, mean height of adult trees in $\mathrm{m} ; G$, basal area in $\mathrm{m}^{2} \mathrm{ha}^{-1}$; Nse, number of seedlings per hectare; Nsa, number of saplings per hectare; ShCov, shrub coverage in \%. Rtree, number of tree. species; and Rshrub, number of shrub species 
Table 14 Stand attributes for the regions of provenance of Fagus sylvatica. Standard deviation between brackets

\begin{tabular}{|c|c|c|c|c|c|c|c|c|c|c|}
\hline Prov & $n$ & $N$ & $D n$ & $H t$ & $G$ & Nse & $N s a$ & ShCov & Rtree & Rshrub \\
\hline 2 & 198 & $\begin{array}{l}444 \\
(408)\end{array}$ & $\begin{array}{l}32.6 \\
(18.3)\end{array}$ & $\begin{array}{l}14.2 \\
(3.7)\end{array}$ & $\begin{array}{l}24.2 \\
(12.9)\end{array}$ & $\begin{array}{l}2221 \\
(2150)\end{array}$ & $\begin{array}{l}394 \\
(914)\end{array}$ & $\begin{array}{l}22.8 \\
(28)\end{array}$ & $\begin{array}{l}2 \\
(1)\end{array}$ & $\begin{array}{l}2 \\
(2)\end{array}$ \\
\hline 3 & 112 & $\begin{array}{l}890 \\
(590)\end{array}$ & $\begin{array}{l}19.5 \\
(7.3)\end{array}$ & $\begin{array}{l}11.2 \\
(2.8)\end{array}$ & $\begin{array}{l}24.9 \\
(11.9)\end{array}$ & $\begin{array}{l}3031 \\
(2447)\end{array}$ & $\begin{array}{l}862 \\
(1210)\end{array}$ & $\begin{array}{l}11.6 \\
(18.7)\end{array}$ & $\begin{array}{l}2 \\
(1)\end{array}$ & $\begin{array}{l}2 \\
(2)\end{array}$ \\
\hline 4 & 23 & $\begin{array}{l}183 \\
(169)\end{array}$ & $\begin{array}{l}43 \\
(25.9)\end{array}$ & $\begin{array}{l}15.3 \\
(6.2)\end{array}$ & $\begin{array}{l}15.1 \\
(11.6)\end{array}$ & $\begin{array}{l}3184 \\
(3614)\end{array}$ & $\begin{array}{l}100 \\
(258)\end{array}$ & $\begin{array}{l}23.4 \\
(22.5)\end{array}$ & $\begin{array}{l}2 \\
(1)\end{array}$ & $\begin{array}{l}3 \\
(3)\end{array}$ \\
\hline 5 & 179 & $\begin{array}{l}605 \\
(592)\end{array}$ & $\begin{array}{l}28 \\
(15.4)\end{array}$ & $\begin{array}{l}13.3 \\
(4.4)\end{array}$ & $\begin{array}{l}26.1 \\
(11.4)\end{array}$ & $\begin{array}{l}2026 \\
(1883)\end{array}$ & $\begin{array}{l}503 \\
(1078)\end{array}$ & $\begin{array}{l}23.9 \\
(32)\end{array}$ & $\begin{array}{l}2 \\
(1)\end{array}$ & $\begin{array}{l}2 \\
(2)\end{array}$ \\
\hline 6 & 111 & $\begin{array}{l}612 \\
(632)\end{array}$ & $\begin{array}{l}26.5 \\
(11.4)\end{array}$ & $\begin{array}{l}15.8 \\
(5)\end{array}$ & $\begin{array}{l}24.2 \\
(11.2)\end{array}$ & $\begin{array}{l}6571 \\
(4542)\end{array}$ & $\begin{array}{l}1151 \\
(1490)\end{array}$ & $\begin{array}{l}21.1 \\
(22.6)\end{array}$ & $\begin{array}{l}2 \\
(1)\end{array}$ & $\begin{array}{l}3 \\
(2)\end{array}$ \\
\hline 7 & 373 & $\begin{array}{l}484 \\
(428)\end{array}$ & $\begin{array}{l}31.5 \\
(15)\end{array}$ & $\begin{array}{l}17.3 \\
(4.9)\end{array}$ & $\begin{array}{l}28.3 \\
(10.6)\end{array}$ & $\begin{array}{l}2356 \\
(2461)\end{array}$ & $\begin{array}{l}303 \\
(617)\end{array}$ & $\begin{array}{l}13.4 \\
(21.5)\end{array}$ & $\begin{array}{l}2 \\
(1)\end{array}$ & $\begin{array}{l}2 \\
(2)\end{array}$ \\
\hline 8 & 431 & $\begin{array}{l}419 \\
(392)\end{array}$ & $\begin{array}{l}31.7 \\
(16)\end{array}$ & $\begin{array}{l}17.3 \\
(6.1)\end{array}$ & $\begin{array}{l}23.8 \\
(10.9)\end{array}$ & $\begin{array}{l}3995 \\
(3350)\end{array}$ & $\begin{array}{l}567 \\
(1146)\end{array}$ & $\begin{array}{l}20.1 \\
(23.7)\end{array}$ & $\begin{array}{l}2 \\
(1)\end{array}$ & $\begin{array}{l}2 \\
(2)\end{array}$ \\
\hline 9 & 321 & $\begin{array}{l}596 \\
(471)\end{array}$ & $\begin{array}{l}27 \\
(12)\end{array}$ & $\begin{array}{l}16.2 \\
(4.8)\end{array}$ & $\begin{array}{l}27.1 \\
(11.4)\end{array}$ & $\begin{array}{l}3609 \\
(3191)\end{array}$ & $\begin{array}{l}753 \\
(1395)\end{array}$ & $\begin{array}{l}9.1 \\
(15.6)\end{array}$ & $\begin{array}{l}2 \\
(1)\end{array}$ & $\begin{array}{l}2 \\
(2)\end{array}$ \\
\hline 12 & 21 & $\begin{array}{l}931 \\
(925)\end{array}$ & $\begin{array}{l}19.1 \\
(8.5)\end{array}$ & $\begin{array}{l}12.3 \\
(5.9)\end{array}$ & $\begin{array}{l}24.7 \\
(15.4)\end{array}$ & $\begin{array}{l}7500 \\
(3750)\end{array}$ & $\begin{array}{l}1619 \\
(1381)\end{array}$ & $\begin{array}{l}17.6 \\
(23.2)\end{array}$ & $\begin{array}{l}2 \\
(1)\end{array}$ & $\begin{array}{l}2 \\
(2)\end{array}$ \\
\hline 13 & 95 & $\begin{array}{l}839 \\
(461)\end{array}$ & $\begin{array}{l}19.9 \\
(6.3)\end{array}$ & $\begin{array}{l}15.2 \\
(3.5)\end{array}$ & $\begin{array}{l}24.7 \\
(8.4)\end{array}$ & $\begin{array}{l}7861 \\
(3905)\end{array}$ & $\begin{array}{l}1719 \\
(1990)\end{array}$ & $\begin{array}{l}26.9 \\
(29.7)\end{array}$ & $\begin{array}{l}2 \\
(1)\end{array}$ & $\begin{array}{l}3 \\
(2)\end{array}$ \\
\hline 14 & 29 & $\begin{array}{l}728 \\
(576)\end{array}$ & $\begin{array}{l}21 \\
(8.2)\end{array}$ & $\begin{array}{l}13.2 \\
(5.3)\end{array}$ & $\begin{array}{l}20.3 \\
(9.1)\end{array}$ & $\begin{array}{l}3987 \\
(2839)\end{array}$ & $\begin{array}{l}466 \\
(589)\end{array}$ & $\begin{array}{l}12.9 \\
(24.2)\end{array}$ & $\begin{array}{l}2 \\
(1)\end{array}$ & $\begin{array}{l}2 \\
(2)\end{array}$ \\
\hline 17 & 222 & $\begin{array}{l}748 \\
(581)\end{array}$ & $\begin{array}{l}23.3 \\
(10.6)\end{array}$ & $\begin{array}{l}14.2 \\
(4.6)\end{array}$ & $\begin{array}{l}25.2 \\
(11)\end{array}$ & $\begin{array}{l}2467 \\
(2214)\end{array}$ & $\begin{array}{l}837 \\
(1337)\end{array}$ & $\begin{array}{l}13.5 \\
(24)\end{array}$ & $\begin{array}{l}2 \\
(1)\end{array}$ & $\begin{array}{l}2 \\
(2)\end{array}$ \\
\hline
\end{tabular}

Prov, region of provenance; $n$, number of plots with basal area of $F$. sylvatica larger than $80 \%$; $N$, number of adult trees per hectare; $D n$, mean diameter of the adult trees in $\mathrm{cm} ; H$, mean height of adult trees in $\mathrm{m} ; G$, basal area in $\mathrm{m}^{2} \mathrm{ha}^{-1} ; N$ se, number of seedlings per hectare; Nsa, number of saplings per hectare; ShCov, shrub coverage in \%. Rtree, number of tree species; and Rshrub, number of shrub species

\section{Annex 2 Maps of the regions of provenance for the 10 species included in the study}



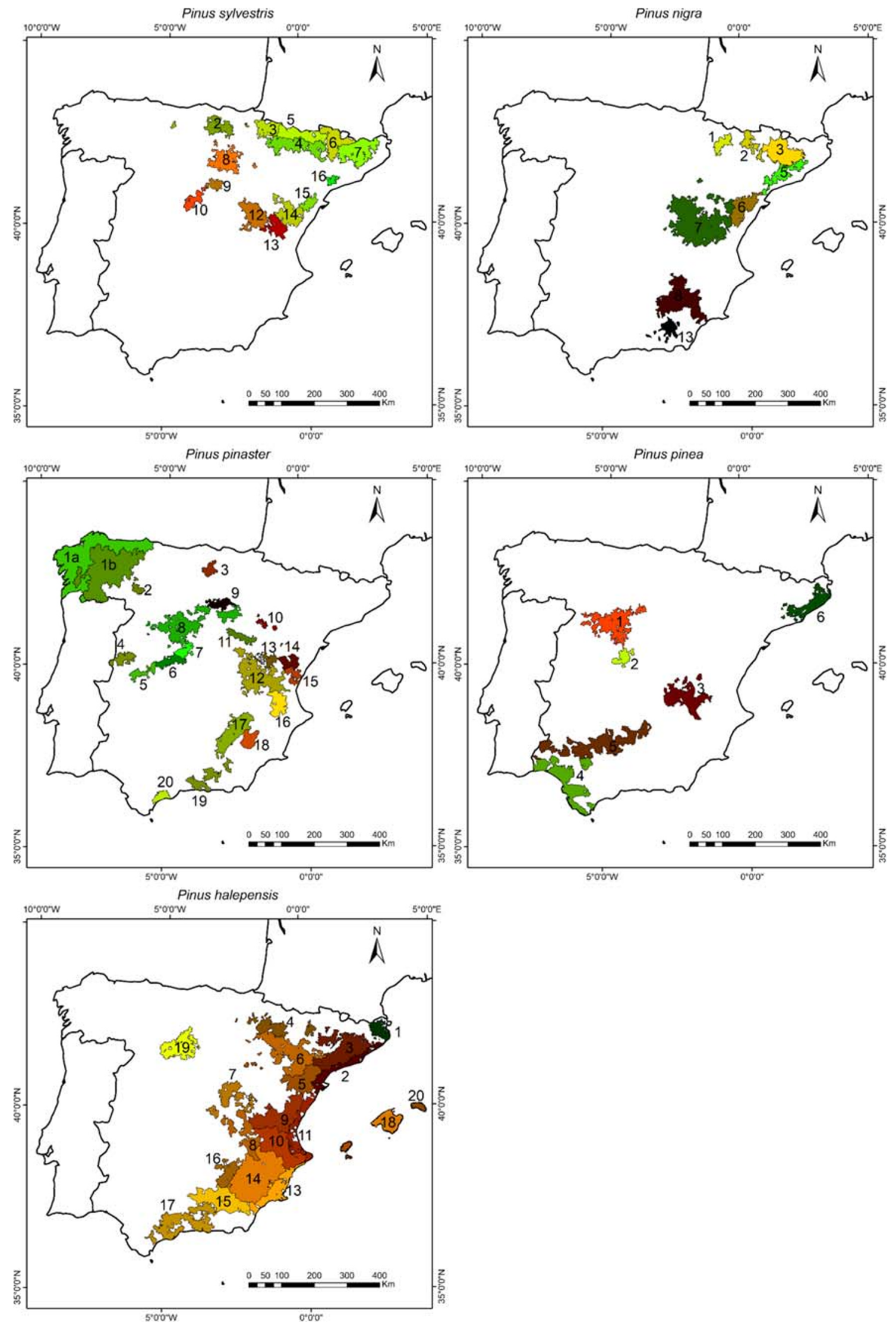

Figure 3 Location of the regions of provenance studied for Pinaceae species. The red color was assigned to the X coordinates (first PCoA axis) of the RP scentroids and green to theY coordinates (second PCoA axis) of the centroids 

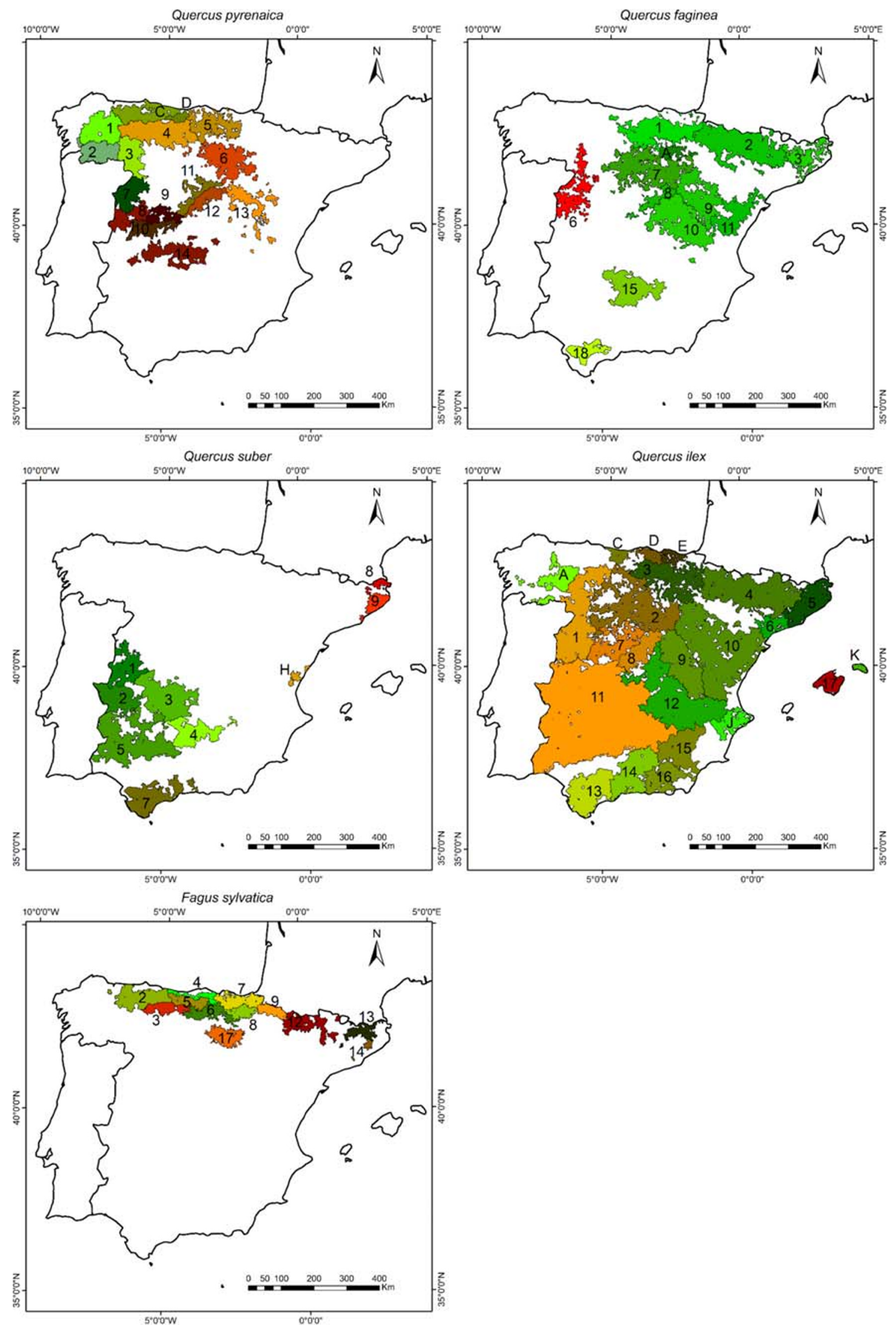

Figure 4 Location of the regions of provenance studied for Fagaceae species. The red color was assigned to the X coordinates (first PCoA axis) of the $\mathrm{RP}$ scentroids and green to the $\mathrm{Y}$ coordinates (second PCoA axis) of the centroids 


\section{References}

Acácio V, Dias FS, Catry FX, Rocha M, Moreira F (2017) Landscape dynamics in Mediterranean oak forests under global change: understanding the role of anthropogenic and environmental drivers across forest types. Glob Chang Biol 23:1199-1217. https://doi.org/10. $1111 /$ gcb. 13487

Alberdi I, Cañellas I, Condes S (2014) A long-scale biodiversity monitoring methodology for Spanish national forest inventory. Application to Álava region. For Syst 23:93-110. https://doi.org/ $10.5424 / \mathrm{fs} / 2014231-04238$

Alberdi I, Hernández L, Condés S, Cañellas I (2016) Spain. In: Vidal C, Alberdi I, Hernández L, Redmond J (eds) National Forest Inventories. Assessment of wood availability and use. Springer, pp 749-769

Alía R, Martín S, de Miguel J et al (1996) Regiones de procedencia Pinus pinaster Aiton. DGCONA, Madrid

Alía R, Alba N, Agúndez D, Iglesias S (2005) Manual para la comercialización y producción de semillas y plantas forestales. Materiales de base y de reproduccióntle. Serie Forestal. DGB, Madrid

Alía R, García del Bario J, Iglesias S et al (2009) Regiones de procedencia de especies forestales en España. Organismo Autónomo de Parques Nacionales, Madrid

Auñón FJ, Garcia del Barrio JM, Mancha JA, et al (2011) Regions of provenance of European beech (Fagus sylvatica L.) in Europe. Genetic resources of European beech (Fagus sylvatica L.) for sustainable Forestry. Ministerio de Ciencia e Innovación, Madrid, pp $141-148$

Barbier S, Gosselin F, Balandier P (2008) Influence of tree species on understory vegetation diversity and mechanisms involved-a critical review for temperate and boreal forests. For Ecol Manag 254:1-15. https://doi.org/10.1016/j.foreco.2007.09.038

Benito-Garzón M, Robson TM, Hampe A (2019) $\Delta$ TraitSDM: species distribution models that account for local adaptation and phenotypic plasticity. New Phytol 222:1757-1765. https://doi.org/10.1111/nph. 15716

Brancalion PHS, Oliveira GCX, Zucchi MI, Novello M, van Melis J, Zocchi SS, Chazdon RL, Rodrigues RR (2018) Phenotypic plasticity and local adaptation favor range expansion of a Neotropical palm. Ecol Evol 8:7462-7475. https://doi.org/10.1002/ece3.4248

Bussotti F, Pollastrini M, Holland V, Brüggemann W (2015) Functional traits and adaptive capacity of European forests to climate change. Environ Exp Bot 111:91-113. https://doi.org/10.1016/J. ENVEXPBOT.2014.11.006

Calama R, Montero G (2007) Cone and seed production from stone pine (Pinus pinea L.) stands in central range (Spain). Eur J For Res 126: 23-35. https://doi.org/10.1007/s10342-005-0100-8

Calama R, Tome M, Sanchez-Gonzalez M et al (2010) Modelling nonwood forest products in Europe: a review. For Syst 19:69-85. https://doi.org/10.5424/fs/201019S-9324

Cañellas I, Del Rio M, Roig S, Montero G (2004) Growth response to thinning in Quercus pyrenaica Willd. coppice stands in Spanish central mountain. Ann For Sci 61:243-250. https://doi.org/10. 1051/forest

Castro J, Zamora R, Hodar JA, Gomez JM (2004) Seedling establishment of a boreal tree species (Pinus sylvestris) at its southernmost distribution limit: consequences of being in a marginal Mediterranean habitat. J Ecol 92:266-277. https://doi.org/10.1111/j.0022-0477. 2004.00870.x

Coll M, Peñuelas J, Ninyerola M et al (2013) Multivariate effect gradients driving forest demographic responses in the Iberian Peninsula. For Ecol Manag 303:195-209. https://doi.org/10.1016/J.FORECO. 2013.04.010
De Luis M, Novak K, Raventós J et al (2011) Climate factors promoting intra-annual density fluctuations in Aleppo pine (Pinus halepensis) from semiarid sites. Dendrochronologia 29:163-169. https://doi. org/10.1016/j.dendro.2011.01.005

Diéguez-Aranda U, Álvarez-González JG, Barrio-Anta M, Rojo Alboreca A (2005) Site quality equations for Pinus sylvestris L. plantations in Galicia (northwestern Spain). Ann For Sci 62:143152. https://doi.org/10.1051/forest:2005006

Ennos RA, Worrell R, Malcolm DC (1998) The genetic management of native species in Scotland. Forestry 71:1-23. https://doi.org/10. 1093/forestry/71.1.1

ESRI (2015) ArcGIS desktop: release 10.3. Redlands, CA: Environmental Systems Research Institute

Esteban LG, Martín JA, de Palacios P et al (2010) Adaptive anatomy of Pinus halepensis trees from different mediterranean environments in Spain. Trees - Struct Funct 24:19-30. https://doi.org/10.1007/ s00468-009-0375-3

Friedrich S, Pauly M (2018) MATS: inference for potentially singular and heteroscedastic MANOVA. J Multivar Anal 165:166-179. https:// doi.org/10.1016/J.JMVA.2017.12.008

Friedrich S, Konietschke F, Pauly (2018) MANOVA.RM: Analysis of Multivariate Data and Repeated Measures Designs

Gandour M, Khouja ML, Toumi L, Triki S (2007) Morphological evaluation of cork oak (Quercus suber): Mediterranean provenance variability in Tunisia. Ann For Sci 64:549-555. https://doi.org/10.1051/ forest:2007032

Gárate-Escamilla H, Hampe A, Vizcaíno-Palomar N et al (2019) Rangewide variation in local adaptation and phenotypic plasticity of fitness-related traits in Fagus sylvatica and their implications under climate change. Glob Ecol Biogeogr 28:1336-1350. https://doi.org/ $10.1111 /$ geb. 12936

Gea-Izquierdo G, Cherubini P, Cañellas I (2011) Tree-rings reflect the impact of climate change on Quercus ilex L. along a temperature gradient in Spain over the last 100years. For Ecol Manag 262:18071816. https://doi.org/10.1016/j.foreco.2011.07.025

González-Martínez SC, Alía R, Gil L (2002) Population genetic structure in a Mediterranean pine (Pinus pinaster Ait.): a comparison of allozyme markers and quantitative traits. Heredity (Edinb) 89:199206. https://doi.org/10.1038/sj.hdy.6800114

Gross CL, Fatemi M, Simpson IH (2017) Seed provenance for changing climates: early growth traits of nonlocal seed are better adapted to future climatic scenarios, but not to current field conditions. Restor Ecol 25:577-586. https://doi.org/10.1111/rec.12474

Harvey BD, Brais S (2007) Partial cutting as an analogue to stem exclusion and dieback in trembling aspen (Populus tremuloides) dominated boreal mixedwoods: implications for deadwood dynamics. Can J For Res 37:1525-1533. https://doi.org/10.1139/X07-090

Jordan L, Clark A, Schimleck LR et al (2008) Regional variation in wood specific gravity of planted loblolly pine in the United States. Can J For Res 38:698-710. https://doi.org/10.1139/X07-158

Konietschke F, Bathke AC, Harrar SW, Pauly M (2015) Parametric and nonparametric bootstrap methods for general MANOVA. J Multivar Anal 140:291-301. https://doi.org/10.1016/J.JMVA.2015.05.001

Krishnamoorthy K, Lu F (2010) A parametric bootstrap solution to the MANOVA under heteroscedasticity. J Stat Comput Simul 80:873. https://doi.org/10.1080/00949650902822564

Lindenmayer DB, Margules CR, Botkin DB (2000) Indicators of biodiversity for ecologically sustainable forest management. Conserv Biol 14:941-950. https://doi.org/10.1046/j.1523-1739.2000.98533. $\mathrm{x}$

Lucas-Borja ME, Fidalgo Fonseca T, Lousada JL et al (2012) Natural regeneration of Spanish black pine [Pinus nigra Arn. ssp. salzmannii (Dunal) Franco] at contrasting altitudes in a Mediterranean mountain area. Ecol Res 27:913-921. https://doi. org/10.1007/s11284-012-0969-x 
Manso R, Calama R, Madrigal G, Pardos M (2013) A silvicultureoriented spatio-temporal model for germination in Pinus pinea L. in the Spanish Northern Plateau based on a direct seeding experiment. Eur J For Res 132:969-982. https://doi.org/10.1007/s10342013-0724-z

Matías L, Abdelaziz M, Godoy O, Gómez-Aparicio L (2018) Disentangling the climatic and biotic factors driving changes in the dynamics of Quercus suber populations across the species latitudinal range. Divers Distrib. https://doi.org/10.1111/ddi.12873

Mayoral C, Calama R, Sánchez-González M, Pardos M (2015) Modelling the influence of light, water and temperature on photosynthesis in young trees of mixed Mediterranean forests. New For 46:485-506. https://doi.org/10.1007/s11056-015-9471-y

McGeoch MA, Schroeder M, Ekbom B, Larsson S (2007) Saproxylic beetle diversity in a managed boreal forest: importance of stand characteristics and forestry conservation measures. Divers Distrib 13:418-429. https://doi.org/10.1111/j.1472-4642.2007.00350.x

Mingeot D, Husson C, Mertens P et al (2016) Genetic diversity and genetic structure of black alder (Alnus glutinosa [L.] Gaertn) in the Belgium-Luxembourg-France cross-border area. Tree Genet Genomes. https://doi.org/10.1007/s11295-016-0981-3

Moreno-Fernández D, Álvarez-González JG, Rodríguez-Soalleiro R et al (2018a) National-scale assessment of forest site productivity in Spain. For Ecol Manag 417:197-207. https://doi.org/10.1016/j. foreco.2018.03.016

Moreno-Fernández D, Hevia A, Majada J, Cañellas I (2018b) Do common silvicultural treatments affect wood density of Mediterranean montane pines ? Forests 9:80. https://doi.org/10.3390/f9020080

Moreno-Fernández D, Ledo A, Martín-Benito D et al (2019) Negative synergistic effects of land-use legacies and climate drive widespread oak decline in evergreen Mediterranean open woodlands. For Ecol Manag 432:884-894. https://doi.org/10.1016/j.foreco.2018.10.023

Mutke S, Gordo J, Chambel MR et al (2010) Phenotypic plasticity is stronger than adaptative differentiation among Mediterranean stone pine provenances. For Syst 19:354. https://doi.org/10.5424/fs/ 2010193-9097

Nabais C, Hansen JK, David-Schwartz R et al (2018) The effect of climate on wood density: what provenance trials tell us? For Ecol Manag 408:148-156. https://doi.org/10.1016/j.foreco.2017.10.040

Oksanen J, Blanchet FG, Friendly M, et al (2018) Vegan: community ecology package

Pardos M, Calama R (2018) Responses of Pinus pinea seedlings to moderate drought and shade: is the provenance a differential factor? Photosynthetica 56:786-798. https://doi.org/10.1007/s11099-0170732-1

Pardos M, Montes F, Aranda I, Cañellas I (2007) Influence of environmental conditions on germinant survival and diversity of Scots pine (Pinus sylvestris L.) in central Spain. Eur J For Res 126:37-47. https://doi.org/10.1007/s10342-005-0090-6

R Core Team (2019) R: A language and environment for statistical computing

Reque J, Bravo F (2008) Identifying forest structure types using National Forest Inventory Data: the case of sessile oak forest in the Cantabrian range. Investig Agrar Sist y Recur For 17:105-113

Rodríguez-García A, Martín JA, López R et al (2015) Influence of climate variables on resin yield and secretory structures in tapped Pinus pinaster Ait. in central Spain. Agric For Meteorol 202:8393. https://doi.org/10.1016/j.agrformet.2014.11.023

Rosenqvist A, Milne A, Lucas R et al (2003) A review of remote sensing technology in support of the Kyoto Protocol. Environ Sci Pol 6:441455. https://doi.org/10.1016/S1462-9011(03)00070-4
Ruiz-Benito P, Gómez-Aparicio L, Zavala MA (2012) Large-scale assessment of regeneration and diversity in Mediterranean planted pine forests along ecological gradients. Divers Distrib 18:1092-1106. https://doi.org/10.1111/j.1472-4642.2012.00901.x

Sánchez-Gómez D, Velasco-Conde T, Cano-Martín FJ et al (2011) Interclonal variation in functional traits in response to drought for a genetically homogeneous Mediterranean conifer. Environ Exp Bot 70:104-109. https://doi.org/10.1016/J.ENVEXPBOT.2010.08.007

Serrada R, Gómez-Sanz V, Aroca MJ et al (2017) Decline in holm oak coppices (Quercus ilex L. subsp. ballota (Desf.) Samp.): biometric and physiological interpretations. For Syst 26:e6. https://doi.org/ $10.5424 / \mathrm{fs} / 2017262-10583$

Simões MP, Belo AF, Fernandes M, Madeira M (2016) Regeneration patterns of Quercus suber according to montado management systems. Agrofor Syst 90:107-115. https://doi.org/10.1007/s10457015-9818-6

Skrøppa T, Fjellstad KB (2017) Conservation of forest genetic resources in Norway in a climate change perspective. Springer, Cham, pp 129-153

Tíscar PA, Linares JC, Tíscar PA, Linares JC (2011) Structure and regeneration patterns of Pinus nigra subsp. salzmannii natural forests: a basic knowledge for adaptive Management in a Changing Climate. Forests 2:1013-1030. https://doi.org/10.3390/f2041013

Valbuena-Carabaña M, de Heredia UL, Fuentes-Utrilla P et al (2010) Historical and recent changes in the Spanish forests: a socioeconomic process. Rev Palaeobot Palynol 162:492-506. https:// doi.org/10.1016/j.revpalbo.2009.11.003

Vannoppen A, Kint V, Ponette Q, Verheyen K, Muys B (2019) Tree species diversity impacts average radial growth of beech and oak trees in Belgium, not their long-term growth trend. For Ecosytems 6: 1-12. https://doi.org/10.1186/s40663-019-0169-z

Vayreda J, Gracia M, Martinez-Vilalta J, Retana J (2013) Patterns and drivers of regeneration of tree species in forests of peninsular Spain. J Biogeogr 40:1252-1265. https://doi.org/10.1111/jbi.12105

Vergarechea M, del Río M, Gordo J, Martín R, Cubero D, Calama R (2019) Spatio-temporal variation of natural regeneration in Pinus pinea and Pinus pinaster Mediterranean forests in Spain. Eur J For Res 138:313-326. https://doi.org/10.1007/s10342-019-01172-8

Vilà-Cabrera A, Martínez-Vilalta J, Vayreda J, Retana J (2011) Structural and climatic determinants of demographic rates of Scots pine forests across the Iberian Peninsula. Ecol Appl 21:1162-1172. https://doi. org/10.1890/10-0647.1

Vizcaíno-Palomar N, Ibáñez I, González-Martínez SC, Zavala MA, Alía $\mathrm{R}$ (2016) Adaptation and plasticity in aboveground allometry variation of four pine species along environmental gradients. Ecol Evol 6: 7561-7573. https://doi.org/10.1002/ece3.2153

Vizcaíno-Palomar N, Ibáñez I, Benito-Garzón M, González-Martínez SC, Zavala MA, Alía R (2017) Climate and population origin shape pine tree height-diameter allometry. New For 48:363-379. https://doi. org/10.1007/s11056-016-9562-4

Yen T-M (2015) Comparing aboveground structure and aboveground carbon storage of an age series of moso bamboo forests subjected to different management strategies. J For Res 20:1-8. https://doi.org/ 10.1007/s10310-014-0455-0

Publisher's note Springer Nature remains neutral with regard to jurisdictional claims in published maps and institutional affiliations. 